Doporučené postupy vycházejí ze soudobých poznatků lékařské vědy a považují se za postupy lege artis. Jde však o doporučení, nikoli předpisy, proto je nutný individuální př́stup ke každému nemocnému. Ošetřující lékař může použít jiný postup, musí však v dokumentaci řádně zdůvodnit, proč se od doporučeného postupu odchýlil.

\title{
Komorové arytmie
}

Doporučený diagnostický a léčebný postup České kardiologické společnosti - inovace 2011

\author{
Autorský kolektiv: Jan Bytešník', Petr Pařízek², Dan Wichterle', Josef Kautzner', Petr Neužil ${ }^{3}$ \\ 'Klinika kardiologie, IKEM, Praha; ${ }^{2}$ I. interní klinika LF UK a FN, Hradec Králové; ${ }^{3}$ Kardiologické oddělení, Nemocnice Na Homolce, Praha
}

Adresa: MUDr. Jan Bytešník, CSc., Klinika kardiologie, IKEM, Vídeňská 1958/9, 14021 Praha 4, e-mail: jan.bytesnik@ikem.cz

\section{1 Úvod}

Komorové arytmie mají různou podobu a klinickou významnost. Jejich nejzávažnější formy vedou rychle $\mathrm{k}$ oběhovému kolapsu či dokonce $\mathrm{k}$ zástavě oběhu a stav pacienta vyžaduje okamžitý léčebný zásah v podobě elektrické kardioverze či defibrilace a kardiopulmonální resuscitace. U všech ostatních komorových arytmií je vhodné před výběrem a aplikací léčby provést podrobnější diagnostické zhodnocení daného stavu - jak to klinická situace umožní včetně rozpoznání případného základního strukturálního srdečního postižení a významnějších komorbidit. Z tohoto komplexnějšího posouzení vychází stanovení prognostické a hemodynamické závažnosti dané arytmie a volba odpovídající léčby. Stručný přehled současných uznávaných diagnostických a léčebných postupů u komorových arytmií, opírajících se o souhrn poznatků medicíny založené na důkazech, je obsahem předložených doporučení České kardiologické společnosti (ČKS). Tento materiál představuje inovaci předchozích doporučených postupů u komorových arytmií, zveřejněných v Cor et Vasa a na webových stránkách ČKS v roce 2005 a respektuje novější relevantní materiály ČKS, Evropské kardiologické společnosti (ESC) či společné materiály ESC a amerických kardiologických společností, publikované v letech 2006-2011. Jsou zde zohledněny i výsledky recentních významných randomizovaných studií a metaanalýz, týkajících se dané problematiky, ze kterých vyplývají důležité závěry pro klinickou praxi v rámci již zmíněné koncepce medicíny založené na důkazech. ${ }^{1-6}$

\section{Definice a klasifikace}

Pojmem komorové arytmie označujeme různé poruchy srdečního rytmu komorového původu (tj. vycházející z myokardu nebo z tkáně převodního systému distálně od Hisova svazku) s frekvencí rychlejší než je klidová frekvence sinusového rytmu či přicházející předčasně a narušující pravidelnost základního rytmu. ${ }^{7-10}$ Pestrá škála komorových arytmií sahá od akcelerovaného idioventrikulárního rytmu a od izolovaných monomorfních komorových extrasystol, přes komplexní formy komorových extrasystol, neudržující se (nesetrvalé) komorové tachykardie (ns-KT), udržující se (setrvalé) monomorfní (s-MKT) a polymorfní komorové tachykardie (s-PKT) až po flutter komor a fibrilaci komor. Třídění komorových arytmií může být podle různých hledisek. Nejvíce používaná je klasifikace komorových arytmií dle elektrokardiografické morfologie ${ }^{3}$ (tabulka 1 ). Z hlediska výběru léčby je podstatná klasifikace dle klinického a prognostického hlediska. ${ }^{3}$

\subsection{Elektrokardiografická klasifikace}

Jak u komorových extrasystol, tak u komorových tachykardií (KT) je možno při hodnocení jejich elektrokardiografické (EKG) morfologie použít označení monomorfní (jeden tvar), bimorfní (dva různé tvary) či polymorfní (více morfologií). ${ }^{7,9}$ Při hodnocení frekvence komorových extrasystol během 24hodinové monitorace je možno použít orientační hledisko vyjadřující průměrný počet komorových extrasystol za jednu hodinu: ${ }^{8}$

> ojedinělé komorové extrasystoly $(<5 / \mathrm{h})$,

> častější komorové extrasystoly $(5-140 / \mathrm{h})$,

> velmi časté komorové extrasystoly (>140/h).

Z tohoto rozdělení je zřejmé, že v kategorii „velmi časté komorové extrasystoly“ (tedy orientačně $\geq 3$ komorové extrasystoly za minutu) mohou být výrazné rozdíly s he- 
Tabulka 1 Elektrokardiografická klasifikace komorových arytmií

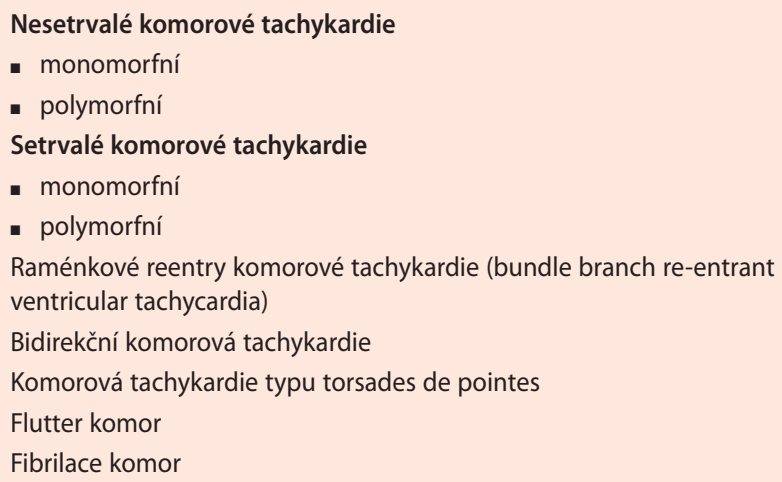

modynamicky značně odlišným dopadem dané arytmie. Vzhledem k tomu, že současné externí monitorovací či dokonce implantabilní systémy nabízejí podrobné zhodnocení arytmií, jeví se jako racionálnější shrnout situaci výstižným popisem výskytu arytmií (morfologie; u komorových extrasystol vazebný interval, četnost a distribuce v čase; u komorových tachykardií frekvence a délka epizod) u individuálního pacienta, než ji označit jednou z výše uvedených kategorií.

Dle formy výskytu komorových extrasystol jsou rozlišovány extrasystoly izolované (samostatné nebo v bi/trigeminické vazbě), či repetitivní (označované jako komplexní formy komorových extrasystol). Ty mohou být v párech (tj. dvě po sobě následující komorové extrasystoly) či ve větším počtu. Sekvence $\geq 3$ komorových extrasystol bývá popisována jako salva komorových extrasystol nebo ns-KT.3,7,9,10 Dle původní hierarchické klasifikace komorových arytmií je sekvence 3-5 komplexů komorového původu označována jako salva komorových extrasystol a pod pojmem ns-KT se rozumí sekvence $\geq 5$ následných ektopických komorových komplexů s frekvencí > 100/min končících spontánně do 30 sekund. ${ }^{10} \mathrm{~V}$ klinické praxi se však obvykle pojmem ns-KT označuje sekvence $\geq 3$ ektopických komorových aktivit. Pokud je trvání uvedené tachykardie $\geq 30$ sekund nebo tachykardie vede do 30 sekund $k$ oběhovému kolapsu či její hemodynamická závažnost vyžaduje intervenci k jejímu ukončení před tímto časovým limitem, nazýváme ji setrvalou komorovou tachykardií (s-KT). ${ }^{7,9,10}$

Označení mnohočetná (multiple) MKT je používáno $\mathrm{v}$ př́ípadě výskytu více než jedné morfologie komorové tachykardie manifestující se spontánně v různých epizodách, nebo indukované časově oddělenými aplikacemi stimulů při diagnostické programované stimulaci.

Naproti tomu označení pleomorfní (mnohotvará) komorová tachykardie vyjadřuje situaci, kdy je zachyceno více morfologií MKT během jedné trvající epizody komorové tachykardie. ${ }^{9}$

Setrvalá komorová tachykardie s morfologií tvaru sinusoidy s frekvencí > 250 za minutu, s nerozlišitelnou morfologií QRS je označována jako flutter komor. Forma komorových tachykardií typu „torsade de pointes“ (TdP) se vyskytuje u stavů s poruchou repolarizace (syndrom dlouhého intervalu QT) a je charakterizována postupným otáčením (rotací) osy komplexů QRS kolem izoelektrické roviny. Pokud je elektrokardiografický interval QTc normální, je měnlivá morfologie komorových tachykardií označována jako polymorfní komorová tachykardie, i když může připomínat tvarem TdP. Při fibrilaci komor je zřejmé úplné vymizení organizované elektrické aktivace komor a na EKG jsou komplexy QRS nahrazeny nepravidelnými kmity a vlnkami, které mají měnlivou amplitudu a vysokou frekvenci, což je spojeno s okamžitou oběhovou zástavou.

Komorové arytmie vznikají v oblasti pod větvením Hisova svazku a ke svému udržení nepotřebují supraventrikulární srdeční struktury ( $\mathrm{tj}$. nad větvením Hisova svazku). Typickým znakem komorových arytmií je rozšířený komplex QRS na EKG (zpravidla $\geq 120$ ms), který není předcházen síňovou aktivitou. Při komorové tachykardii bývá přítomna síňokomorová disociace, ale v řadě př́ípadů může být zachováno retrográdní vedení na síně. Diferenciální diagnostika tachykardií se širokým komplexem QRS je zmíněna $\mathrm{v}$ dalším textu.

\subsection{Klinická a prognostická klasifikace}

Na rozdíl od supraventrikulárních tachyarytmií, kde je při indikaci léčby ve většině př́padů hlavním cílem ovlivnění symptomů, stojí v popředí při výběru léčby komorových arytmií hledisko prognostické. Vychází to z faktu, že komorové tachyarytmie jsou jednoznačně nejčastější příčinou náhlé srdeční smrti, která dosud zůstává dominantním problémem současné medicíny v ekonomicky rozvinutých zemích. Novější údaje uvádějí, že výskyt náhlé srdeční smrti v USA je kolem 250-300 000 prrípadů ročně, což odpovídá výskytu zhruba 1-1,5 000 úmrtí ze skupiny náhlých srdečních smrtí na 1 milion obyvatel. ${ }^{3,11-15}$ Náhlá srdeční smrt je zodpovědná za více než polovinu všech úmrtí z kardiální příčiny. ${ }^{11-15}$ Je velmi pravděpodobné, že incidence náhlé srdeční smrti v průmyslově vyspělých evropských státech je obdobná. ${ }^{3,16}$ Téměř v $90 \%$ prrípadů je jako hlavní přičina závažných komorových arytmií v celé populaci uváděna ischemická choroba srdeční, zejména akutní i chronické stadium infarktu myokardu. ${ }^{16}$

V současnosti je preferována tzv. prognostická klasifikace komorových arytmií, která kromě frekvence a formy arytmie zohledňuje především základní strukturální srdeční postižení, velikost a kontraktilní funkci levé komory a další klinické ukazatele. ${ }^{17-19}$

Dle prognostické klasifikace jsou komorové arytmie rozdělovány do tří skupin:

> benigní (komorové extrasystoly a ns-KT bez prokazatelného strukturálního srdečního postižení či poruchy repolarizace), 
> prognosticky významné - potenciálně maligní (komplexní formy komorových extrasystol a ns-KT u pacientů se strukturálním srdečním postižením nebo hemodynamicky tolerované s-KT bez významnějšího organického srdečního onemocnění),

> maligní (fibrilace komor, flutter komor a hemodynamicky velmi závažné s-KT - u všech stavů - tedy i bez zjevného organického srdečního postižení, dále s-MKT, s-PKT, TdP při strukturálním srdečním onemocnění či při poruše průběhu repolarizace).

\section{Arytmogenní mechanismy, patofyziologie}

Komorová tachykardie při strukturálním postižení myokardu (stav po IM, fibróza či dysplazie myokardu u dilatační kardiomyopatie, arytmogenní kardiomyopatie, non-kompaktní kardiomyopatie, hypertrofie myokardu aj.), mohou vznikat na podkladě všech tří hlavních arytmogenních mechanismů - tj. abnormální automacie, spouštěné aktivity při časné či opožděné následné depolarizaci a na podkladě návratného vzruchu (reentry). ${ }^{4,9}$

V akutní fázi ischemického poškození myokardu se uplatňují střrídavě či souběžně všechny tři výše vyjmenované mechanismy. ${ }^{20,21}$

Tachykardie typu reentry tvoří největší část s-KT po IM. Změněná struktura myokardu, kde jizevnatá tkáň tvoří bariéru vůči šíření vzruchu, a částečně postižený okolní myokard (v němž dochází ke zpomalení vedení vzruchu) představují arytmogenní substrát pro vznik a udržení tzv. makro-reentry mechanismu. Některé práce ukázaly rozdíly v rozsahu a charakteristice poinfarktové jizvy u pacientů s indukovatelnou komorovou tachykardií ve srovnání s pacienty bez vyvolatelné tachykardie: u pacientů s vyvolatelnou komorovou tachykardií byl větší rozsah jizvy (dle vyšetření magnetickou rezonancí metodou pozdní opacifikace [delayed-enhancement, DE-MR]) a při elektroanatomickém mapování byla u nich významně nižší voltáž v oblastech s abnormálními a frakcionovanými signály a byl větší počet míst s pozdními potenciály, izolovanými izoelektrickým segmentem od příslušného komorového elektrogramu. ${ }^{21}$

Jizevnatá (nebo fibrolipomatozní) tkáň je podkladem arytmií typu reentry i u kardiomyopatií nebo u nemocných s chlopenními vadami. Arytmogenní substrát pro okruh reentry se také může vytvořit v delším odstupu po kardiochirurgické korekci vrozené srdeční vady, při níž je provedena ventrikulotomie nebo použita záplata.

Pokud není př́tomno zjevné strukturální postižení myokardu, bývají komorové arytmie podmíněny jiným mechanismem. Tak napríklad idiopatické komorové tachykardie z výtokového traktu pravé komory vznikají nejčastěji na podkladě spouštěné aktivity nebo abnormální automacie, navozené katecholaminy.22 Tyto tachykardie jsou často vyvolány fyzickou zátěží či psychickým stresem. Také idiopatické komorové tachykardie z levé komory mívají podklad v abnormální automacii pod vlivem katecholaminů. Mohou být též důsledkem spouštěné aktivity (tzv. adenosin-senzitivní tachykardie) nebo intrafascikulárního reentry (tzv. verapamil-senzitivní tachykardie).

Na pravděpodobný arytmogenní mechanismus můžeme usuzovat z klinické a EKG charakteristiky arytmie, elektrofyziologické charakteristiky při invazivním vyšetření a z odpovědi arytmie na neurostimulační podněty a určitá farmaka. ${ }^{20}$

U některých typů komorových arytmií byl identifikován genetický podklad - tj. genové mutace nebo genový polymorfismus, které jsou zodpovědné za abnormální funkce určitého iontového kanálu. Diagnostika v tomto směru pokročila zejména u syndromu dlouhého intervalu QT (LQTS), kde je rozlišováno několik typů tohoto postižení, u nichž byly rozpoznány abnormální geny, způsobující poruchu iontových kanáli̊, které se podílejí na průběhu repolarizace., ${ }^{3,23}$ Výsledkem je disperze repolarizace, jako jedna z podmínek vzniku reentry mechanismu.

Rozpoznání arytmogenních mechanismů jednotlivých arytmií přispívá $\mathrm{k}$ racionálnějšímu výběru odpovídající terapie. Pochopení mechanismu určitých typů komorových tachykardií přineslo přesvědčivý efekt zejména $\mathrm{v}$ podobě účinné nefarmakologické terapie, tj. cílených katetrizačních či chirurgických ablací, které ovlivní „kritickou“ oblast myokardu podílející se na arytmogenním mechanismu nebo v optimálně nastaveném režimu antitachykardické stimulace $\mathrm{u}$ implantabilních kardioverterů-defibrilátorů. ${ }^{3,4,9}$

Též je třeba zdůraznit, že kromě arytmogenního substrátu se na vzniku a udržení komorových arytmií uplatňují také další faktory, které označujeme jako vyvolávající (např. extrasystola, neudržující se komorová tachykardie, náhlá změna srdeční frekvence, bradykardie) a modulující (ischemie myokardu, hypoxemie, katecholaminy lokální i cirkulující, iontová dysbalance, abnormální neurovegetativní modulace, změna napětí myocytů aj.). Při léčbě je pozornost cílena i na ovlivnění těchto faktorů. ${ }^{3,4}$

\section{Klinická manifestace a epidemiologie}

Subjektivní vnímání různých arytmií je velmi individuální a platí to i pro komorové arytmie. Je ovlivněno mimo jiné přítomností a stupněm základního kardiálního postižení, stavem cerebrovaskulární cirkulace, přítomností dalších onemocnění i psychickým stavem pacienta. Někteří jedinci jsou velmi citliví i na sporadické, izolované komorové extrasystoly a nepř́jemně vnímají zejména postextrasystolické pauzy. Na druhé straně i setrvalá komorová tachykardie (s-KT) s frekvencí < 180/min může probíhat bez výraznějších symptomů, zvláště u pacientů bez závažnějšího organického srdečního postižení. Obvykle jsou však s-KT spojeny se závažnými příznaky podmíněnými hypotenzí, nízkým minutovým výdejem, projevy akutní koronární nedostatečnosti, srdečním selháním či cerebrovaskulární insuficiencí. Fibrilace komor, flutter komor a hemodynamicky nejzávažnější formy s-KT (obvykle s frekvencí > 200/min) jsou provázeny rychle vzniklým bezvědomím až oběhovou zástavou. 
Dle současných guidelines ESC a amerických kardiologických společností jsou komorové arytmie z hlediska klinické manifestace (symptomů) klasifikovány jako hemodynamicky stabilní (asymptomatické či minimálně symptomatické) a hemodynamicky nestabilnỉ (tabulka 2).

Z klinického hlediska jsou důležitou informací též okolnosti předcházející vzniku komorové tachykardie, jako výrazná fyzická zátěž, emoční stres apod. Akutní ischemie myokardu či srdeční selhání mohou být spouštěcím momentem pro vyvolání a udržení s-KT nebo fibrilace komor. U některých arytmií může přispět k jejich vyvolání dysbalance minerálů v organismu (zejména kalia a kalcia), vliv některých farmak, toxinů či jiných působků - faktorů, které ovlivňují funkci iontových kanálů kardiomyocytů, a tak depolarizační a především repolarizační fázi srdečního cyklu.

\section{Epidemiologie}

Komorové extrasystoly lze zachytit při provádění krátkého záznamu EKG v klidu asi u 1-2 \% osob, které nemají prokazatelné srdeční postižení. Jejich výskyt stoupá s věkem a je výrazně vyšší u pacientů s organickým srdečním onemocněním. Při 24hodinovém ambulantním monitorování EKG lze zachytit ojedinělé komorové extrasystoly zhruba u 50 \% zdravých osob. Při šestihodinové monitoraci EKG u mužů středního věku, bez známek strukturálního srdečního postižení, byly asymptomatické komorové extrasystoly zachyceny u více než $60 \%$ vyšetřených. ${ }^{3} \mathrm{U}$ pacientů s koronární nemocí či dilatační kardiomyopatií se vyskytují komorové extrasystoly až u 90-95 \% a komplexní formy komorových extrasystol až u $80 \%$ vyšetřených. ${ }^{24,25}$

Je třeba brát $\mathrm{v}$ úvahu, že existuje poměrně značná spontánní variabilita frekvence komorových extrasystol v rámci 24hodinového cyklu či během delších časových úseků. Dle některých studií byly rozdíly četnosti spontánního výskytu komorových extrasystol za 24 hodin ve dvou různých záznamech v rozmezí jednoho týdne až $70 \%$, pokud byl při prvním vyšetření průměrný počet méně než 200 komorových extrasystol za jednu hodinu. Při výskytu četnějších komorových extrasystol se tato spontánní variabilita snižuje. Tak například při průměrném počtu více než 1000 komorových extrasystol za jednu hodinu při 24 hodinovém

\section{Tabulka 2 Klasifikace komorových arytmií z hlediska klinické manifestace (symptomů)}

\begin{tabular}{l} 
Hemodynamicky stabilní \\
- asymptomatické \\
- minimálně symptomatické (palpitace, vnímání nepravidelné \\
srdeční akce) \\
Hemodynamicky nestabilní vedoucí k některé z následujících \\
klinických situací: \\
- presynkopa \\
- synkopa \\
- náhlá srdeční smrt (do jedné hodiny od začátku symptomů) \\
- překonaná náhlá oběhová zástava (kdy léčebný výkon odvrátí \\
fatální situaci) \\
\hline Upraveno dle citace 3.
\end{tabular}

záznamu byla spontánní variabilita četnosti komorových extrasystol jen $13 \%{ }^{26}$ Tento jev je třeba brát v úvahu při posuzování účinku testovaných léčiv pro potlačení ektopické aktivity, provázené symptomy. Řada autorů vyžadovala pro posouzení účinného medikamentózního potlačení symptomatické komorové extrasystolie snížení výskytu izolovaných komorových extrasystol nejméně o $80 \%$ a u komplexních forem komorových extrasystol a ns-KT snížení dokonce o $90 \%{ }^{17,26,27} \mathrm{~V}$ současné době je možno frekventní komorové extrasystoly ovlivňovat antiarytmiky u pacientů se zvýšeným rizikem náhlé srdeční smrti při současném zajištění implantabilním kardioverterem-defibrilátorem (ICD). Pokud dominuje jedna morfologie komorových extrasystol, lze zvážit i její ovlivnění katetrizační ablacíi, ${ }^{3,4}$ - viz dále.

Častost výskytu $n s-K T$ závisí na základním srdečním onemocnění. U osob bez zjevného srdečního postižení lze ns-KT zachytit při 24 hodinovém holterovském monitorování EKG v 1-3 \%. V prvních 24 hodinách po vzniku akutního infarktu myokardu je výskyt ns-KT udáván zhruba ve $45 \%$ př́padů. U chronických stadií ischemické choroby srdeční se jejich četnost pohybuje okolo $10 \%$, a to především u osob se sníženou funkcí levé srdeční komory. ${ }^{25,26}$

$\mathrm{U}$ pacientů s výraznou hypertrofií levé komory se ns-KT vyskytují až v 10-12\%.

U hypertrofické kardiomyopatie je výskyt ns-KT ještě vyšší a u pacientů s anamnézou synkop při této základní diagnóze dosahuje až $70 \%$. Velmi častá je ns-KT u pacientů s dilatační kardiomyopatií, kde př̀i 24 hodinovém ambulantním monitorování EKG lze zachytit uvedenou arytmii až v 50 \% prrípadů, a to i u asymptomatických jedinců. . $^{3,24,26,28}$

$\mathrm{V}$ předchozím textu jsou uvedeny kvalifikované odhady o výskytu náhlé srdeční smrti v průmyslově vyspělých zemích, které uvádějí roční výskyt náhlé srdeční smrti mezi 1-2 př́pady/1 000 obyvatel. ${ }^{3,15,16,29-33}$ Nejčastějším arytmickým podkladem náhlé srdeční smrti jsou komorové tachykardie nebo fibrilace komor, které odpovídají za 85 \% př́ípadů těchto úmrtí. ${ }^{34}$ Výskyt $s-K T$ v prvním období (od 3. dne do konce 6. týdne) po IM je kolem $1 \%$, v dalším období se výskyt s-KT pohybuje kolem 5-10 \% za rok a je zřetelně vyšší při výrazně snížené systolické funkci levé komory. ${ }^{3,35}$ U neischemických kardiomyopatií je výskyt s-KT při ročním sledování obdobný. Při diagnóze chronického srdečního selhání je podíl náhlé srdeční smrti na celkové mortalitě dominantní (zhruba dvě třetiny) ve funkční tř́dě II (klasifikace NYHA), zatímco ve funkční třídě III a zejména IV je převažující příčinou smrti progresivní srdeční selhání.

\section{Diagnostika a diferenciální diagnostika}

Základem diagnostiky komorových arytmií je standardní elektrokardiogram. Jak je uvedeno výše, typickým nálezem při komorové tachykardii je šíře QRS > 0,12 s na elektrokardiogramu. Rozšíření komorového komplexu na povrchovém EKG však nemusí znamenat, že jde o komorovou tachykardii. Rozlišení tachykardií se širokým QRS komplexem ( $\geq 0,12 \mathrm{~s})$ - tedy komorových tachykardií 
a supraventrikulárních tachykardií s aberací komorového vedení či s komorovou preexcitací - dle EKG kritérií se opírá o dostatečně ověřené algoritmy. Je přitom posuzována přítomnost síňo-komorové disociace, tvar komorového komplexu a časový průběh jeho jednotlivých komponent. ${ }^{36}$ Typickým nálezem, svědčícím pro komorovou tachykardii je monofázický kmit $\mathrm{R}$ ve svodu $\mathrm{V}_{1}$, převážně pozitivní konkordantní tvar komplexu QRS ve všech hrudních svodech a levostranný sklon osy srdeční ve frontální rovině. Všeobecně uznávaný je algoritmus podle P. Brugady a spol., který má vysokou senzitivu (> 98 \%) i specificitu (téměř 97 \%) pro správné rozlišení supraventrikulárních tachykardií od komorových tachykardií. ${ }^{37} \mathrm{Na}$ tomto místě je třeba zdůraznit důležitost zachycení 12svodového záznamu EKG v průběhu tachykardie, aby bylo $\mathrm{k}$ dispozici pro srovnání se stimulačně vyvolanou tachykardií v prrípadě nefarmakologické cílené léčby. Kontinuální registrace EKG má být zajištěna při použití vagových manévrů či při nitrožilní aplikaci léku (např́klad adenosinu) k ukončení tachykardie. Dále je třeba připomenout, že při každé tachykardii se širokým komplexem QRS, má být z hlediska bezpečnosti pacienta postupováno $v$ úvodní fázi léćby tak, jako by šlo o komorovou tachykardii. ${ }^{3,36}$

U sporadicky se vyskytujících symptomů budících podezření na arytmický podklad je možno využít některou z forem ambulantního monitorování EKG (24-48hodinové, prrípadně delší holterovské monitorování EKG, epizodický záznamník EKG, transtelefonický přenos EKG, případně i implantabilní záznamník EKG). Důležitou diagnostickou roli při detekci některých forem komorových tachykardií může mít zátěžový EKG test.

$\mathrm{V}$ př́padech, kde je EKG diagnostika nepřesvědčivá, je třeba upřesnit diagnózu pomocí invazivního elektrofyziologického vyšetření, které je též využíváno k posouzení vyvolatelnosti s-KT v rámci stratifikace rizika náhlé srdeční smrti. Toto vyšetření má být prováděno na pracovišti, které je schopno poskytnout komplexní léčbu komorových arytmií, včetně nefarmakologických léčebných postupů. ${ }^{4}$

Při detekci komorových arytmií na EKG je třeba zajistit další vyšetření k potvrzení, či vyloučení strukturálního srdečního onemocnění. Této problematice je věnována následující část o rizikové stratifikaci pacientů s komorovou arytmií.

\section{Stratifikace rizika náhlé arytmické smrti}

Efektivní prevence náhlé srdeční smrti v určité populaci je dána nejen stratifikačním schématem (predikční silou použitých testů včetně jejich dostupnosti a nákladnosti), ale také prríslušnou incidencí náhlé srdeční smrti spolu s finančními náklady a riziky relevantní léčby, kterou v současnosti představuje především implantace ICD. Z těchto důvodů není realizovatelná plošná stratifikace rizika a prevence náhlé srdeční smrti. Z praktického medicínského i ekonomického hlediska zde proto připadá v úvahu jen doporučení k úpravě životosprávy a ke kontrole rizikových faktorů ischemické choroby srdeční, což má za cíl snížení incidence tohoto onemocnění, jehož podíl na výskytu náhlé srdeční smrti je dominantní.
Současná stratifikace rizika náhlé srdeční smrti a navazující léčebná strategie je výhradně cílena do preselektované populace pacientů s určitými charakteristikami srdečního onemocnění, i když je tím podchycena jen relativně malá část incidence náhlé srdeční smrti v obecné populaci.

U vzácnějších strukturálních srdečních onemocnění nebo vrozených poruch iontových kanálů je stratifikace rizika náhlé srdeční smrti založena převážně na klinických nebo na individuálně specifických ukazatelích pro jednotlivá onemocnění.

Jasným rizikovým ukazatelem - bez ohledu na základní srdeční postižení - je spontánní výskyt udržující se (setrvalé) komorové arytmie. Dle tohoto aspektu označujeme prevenci náhlé srdeční smrti jako sekundární („post-event“, tj. u pacientů s dokumentovanou s-KT či dokonce po kardiopulmonální resuscitaci pro s-KT/fibrilace komor) a primární („pre-event“, tj. u pacientů, kteří mají dle určitých ukazatelů vyšší riziko náhlé arytmické smrti, avšak dosud se u nich s-KT nemanifestovala). ${ }^{1-3}$

Záchyt klinické (tj. spontánně vzniklé) udržující se hemodynamicky významné komorové arytmie představuje závažný faktor zvyšující výrazně riziko náhlé srdeční smrti jak u pacientů s ischemickou i neischemickou kardiomyopatií, tak u pacientů s tzv. „primárně elektrickou“ srdeční poruchou. ${ }^{1,229,38-42,43}$ Riziková stratifikace v rámci primární prevence náhlé srdeční smrti má některá specifika daná základní kardiální diagnózou. ${ }^{1,34} \mathrm{U}$ jednotlivých diagnostických jednotek je uvedeno též stanovisko k př́padné indikaci léčby ICD.

\subsection{Koronární nemoc a dilatační kardiomyopatie}

Následující text se týká ischemické choroby srdeční (včetně stavů po infarktu myokardu) a neischemické dilatační kardiomyopatie - tedy dvou nejvíce prevalentních strukturálních srdečních onemocnění, u nichž výzkum klinických, neinvazivních i invazivních prediktorů náhlé srdeční smrti a výsledky studií s ICD, kam byli zařazeni pacienti s oběma uvedenými diagnózami, vedl k vypracování poměrně homogenního a obecně uznávaného schématu stratifikace rizika náhlé srdeční smrti. ${ }^{1-3,5}$

$\mathrm{V}$ rámci sekundární prevence náhlé srdeční smrti je plně akceptována implantace ICD (indikační třída I, úroveň důkazů $\mathrm{A}$ - dle kritérií medicíny založené na důkazech), což se opírá o výsledky tří multicentrických randomizovaných studií (AVID, CIDS, CASH), jejichž analýzy byly opakovaně komentovány $\mathrm{v}$ předchozích doporučeních $\mathrm{k}$ léčbě ICD. ${ }^{1-3}$

Posuny v indikacích $\mathrm{k}$ léčbě ICD jsou především v oblasti primární prevence náhlé srdeční smrti.

$\mathrm{V}$ úvodu je třeba zdůraznit, že klinické rozhodování cílené na prevenci náhlé srdeční smrti by nemělo být zcela a rigidně založeno na periodicky publikovaných doporučených postupech, které nemohou plně postihnout kvazikontinuální aktualizaci důkazů a expertních konsensů. $\mathrm{K}$ interpretaci poznatků, týkajících se rizikové stratifikace náhlé srdeční smrti je vhodné znát její teoretické pozadí, problémy a limity, mezi něž patří: 
> dichotomizace rizikové populace kontrastuje s rizikem náhlé srdeční smrti, které je kontinuální veličinou;

> rizikové prediktory náhlé srdeční smrti jsou současně kvantitativně srovnatelnými prediktory nearytmické kardiální mortality;

> některé maligní arytmie jsou jen epifenoménem srdečního selhání nebo ischemie a jejich léčba ICD neprodlužuje signifikantně přežívání, nebo jen mění způsob úmrtí;

> prediktory rizika náhlé srdeční smrti mají omezenou reproducibilitu a navíc se mění s klinickým vývojem (zejména $\mathrm{v}$ časné, ale i v pozdější fázi po IM), takže jednorázové stanovení míry rizika náhlé srdeční smrti může být $\mathrm{u}$ individuálního pacienta $\mathrm{v}$ dlouhodobé perspektivě výrazně nadhodnoceno, či naopak podhodnoceno;

> moderní farmakoterapie ICHS a zejména reperfuzní léčba akutního IM prodělala v posledních letech zásadní vývoj, a proto není možné jednoznačně extrapolovat výsledky historických studií do současnosti;

> pozitivní predikční hodnota všech rizikových faktorů náhlé srdeční smrti (včetně ejekční frakce levé komory) je relativně nízká - navíc trvající trend ke zlepšení prognózy pacientů se strukturálním srdečním onemocněním, a tedy snížení pre-testové pravděpodobnosti náhlé srdeční smrti vede $\mathrm{k}$ poklesu pozitivní predikční hodnoty jednotlivých stratifikátorů rizika;

> multifaktoriální stratifikace rizika náhlé srdeční smrti může být časově, organizačně a ekonomicky náročná, a navíc zvýšení pozitivní predikční hodnoty pomocí této strategie je dosaženo na úkor senzitivity.

Bylo by možné jmenovat ještě řadu dalších limitací současné stratifikace rizika náhlé srdeční smrti, nicméně v klinické praxi musíme akceptovat současný stav řešení, i když víme, že není optimální.

Kromě selektivní koronarografie, potvrzující nebo vylučující významnou koronární nemoc (a demonstrující případné přetrvávající rizikové nálezy na věnčitých tepnách), echokardiograficky stanovené ejekční frakce levé komory srdeční jako globálního ukazatele funkce srdeční pumpy včetně funkčního stavu (NYHA), různých metod k detekci spontánních arytmií (klidové a zátěžové EKG, Holter, externí epizodní nebo implantabilní záznamníky EKG) a invazivních elektrofyziologických testů byla zkoumána celá škála metod k neinvazivní detekci faktorů nutných pro vznik a udržení maligních arytmií. Můžeme je rozdělit do podskupin charakterizujících komorovou depolarizaci (šíre komplexu QRS, fragmentace komplexu QRS, pozdní komorové potenciály), repolarizaci (interval QT, disperze QT, variabilita QT, dynamicita QT a variabilita a alternans vlny T) a srdeční autonomní regulace (variabilita srdeční frekvence, baroreflexní senzitivita, turbulence srdeční frekvence, decelerační kapacita srdeční frekvence a pozátěžové zotavení srdeční frekvence).

Některé z těchto testů vykazují silnější predikční charakteristiky pro náhlou srdeční smrt než ejekční frakce levé komory a měly by potenciál pro selektivnější výběr pacientů pro léčbu ICD. Vstupní kritéria již dokončených (a pozitivních) ICD studií ale byla pragmaticky založena na prrítomnosti významné systolické dysfunkce levé komory. Přestože průkaz účinnosti léčby ICD neuznává tuto strategii jako optimální, nelze z etických a legálních důvodů do budoucna předpokládat, že by byla koncipována studie, která by indikaci léčby ICD, vyplývající z těchto studií, výrazněji omezila. Spíše by mohlo jít o určité zpřesnění stratifikace u některých podskupin pacientů s ischemickou a neischemickou kardiomyopatií. Vyplývá to $\mathrm{z}$ toho, že přes zdánlivou jednoznačnost výsledků ICD studií některé dodatečné („post-hoc“) podskupinové analýzy naznačují, že jednoduchý klinický skórovací systém umožňuje identifikovat pacienty, kteří nemusejí mít prospěch z profylaktické implantace ICD bud' proto, že jsou relativně zdraví, nebo naopak vykazují signifikantní kombinaci komorbidit.

Při stratifikaci rizika náhlé srdeční smrti je třeba také vzít v potaz odhadovanou dobu přežívání s ohledem na kardiální a nekardiální onemocnění, protože doba expozice riziku náhlé srdeční smrti je nepochybně zásadním faktorem pro př́nos z léčby ICD.

Výše uvedené neinvazivní prediktory mohou hrát významnou roli při plánování budoucích primárně preventivních studií s ICD v populaci pacientů s lehkou/střední dysfunkcí (ejekční frakce levé komory [EFLK] > 35 \%), ze které se $\mathrm{v}$ absolutních číslech rekrutuje značná část kandidátů náhlé srdeční smrti. Kromě klinických a neinvazivně elektrofyziologických ukazatelů rizika se mohou také uplatnit biomarkery, genetické determinanty nebo rozsah myokardiálního jizvení kvantifikovaný magnetickou rezonancí.

Vzhledem ke skutečnosti, že koronární nemoc je zodpovědná za největší počet náhlé srdeční smrti na podkladu KT, je otázce rizikové stratifikace pacientů s touto diagnózou věnována mimořádná pozornost. Stratifikace zatím asymptomatických pacientů s ICHS není prakticky možná. Hlavní pozornost je nadále zaměřena na podskupinu pacientů po prodělaném IM. I v současné éře časné reperfuzní léčby infarktu myokardu s menším následným poškozením systolické funkce levé komory trvá u těchto pacientů vyšší riziko celkové kardiální i arytmické mortality. ${ }^{1-3,25,31}$ Žádná $\mathrm{z}$ hodnocených metod se zatím přesvědčivě a reprodukovatelně neukázala být $\mathrm{v}$ klinické praxi př́nosnější než jednoduché vyšetření EFLK, posouzení funkční třídy, kde je zvýšené riziko náhlé srdeční smrti především ve třídě II-III, a šíře komplexu QRS (kdy je rizikovým nálezem hodnota $>120 \mathrm{~ms}$ ). Jak je již uvedeno výše - dosavadní zkušenosti ukazují, že předpovědní hodnota stratifikačních testů se mění v závislosti na časovém odstupu od IM.

Dosavadní doporučení pro rizikovou stratifikaci po IM na základě výsledků primárně profylaktických studií s ICD shrnuje tabulka 3. Je zde zohledněn interval od IM, stupeň systolické dysfunkce LK a prrípadný záchyt ns-KT při monitoraci EKG. V rámci rizikové stratifikace je u některých pacientů opodstatněné provést programovanou stimulaci komor a při indukovatelnosti s-KT je vhodná indikace 
Tabulka 3 Současná riziková stratifikace, vedoucí k indikaci léčby $I C D$ v rámci primární profylaxe náhlé srdeční smrti u pacientů s ICHS, po infarktu myokardu a u pacientů s neischemickou dilatační kardiomyopatií

\section{Ischemická choroba srdeční, stav po IM}

- $V$ průběhu prvních 40 dnů po $I M$, při nálezu snižené $E F L K \leq 35 \%$ a prí záchytu ns-KT při monitoraci EKG v odstupu $>48$ hodin od vzniku infarktu je opodstatněné provést programovanou stimulaci komor a při indukovatelnosti s-KT je vhodná indikace primárně profylaktické implantace ICD (indikační třída I, úroveň důkazů A)

- V delším odstupu po IM (> 40 dnů), pokud trvá EFLK $\leq 35 \%$ a funkční stav NYHA II-III nebo funkční stav NYHA I při EFLK $\leq 30 \%$, je vhodná indikace primárně profylaktické implantace ICD (indikační trí́da I, úroveň důkazů $A$ )

- $V$ delším odstupu po IM, prì nálezu snižené $E F L K \leq 40 \%$ a při záchytu ns-KT při monitoraci EKG a při indukovatelnosti s-KT při elektrofyziologickém testování je vhodná indikace primárně profylaktické implantace ICD (indikační třída I, úroveň důkazů B).

Neischemická dilatační kardiomyopatie

- U dilatační kardiomyopatie, s EFLK $\leq 35 \%$ a funkčním stavem NYHA II-III i při optimální farmakoterapii je vhodná indikace primárně profylaktické implantace ICD (indikační tř́ida I, úroveň důkazů A)

EFLK - ejekční frakce levé komory, EKG - elektrokardiogram, ICD - implantabilní kardioverter-defibrilátor, IM - infarkt myokardu, NYHA - New York Heart Association, s-KT - setrvalá komorová tachykardie.

Upraveno dle citaci $1-3$

primárně profylaktické implantace ICD (indikační třída I, úroveň důkazů $\mathrm{A}$ ).

Neischemická dilatační kardiomyopatie vykazuje pětiletou mortalitu od stanovení diagnózy zhruba $20 \%$, přičemž $\mathrm{z}$ jedné třetiny se na mortalitě podílí náhlá srdeční smrt. U pacientů s pokročilým srdečním selháním je podíl náhlé srdeční smrti téměř $50 \%$.,24,44,45 Zřetelnými prediktory náhlé srdeční smrti u idiopatické dilatační kardiomyopatie (DKMP) je nízká EFLK $\leq 30 \%$, progrese dilatace LK, systémová hypotenze, hyponatremie a perzistující fibrilace síní. ${ }^{3}$ Riziko náhlé srdeční smrti je zřetelně vyšší u pacientů s výskytem synkopy a se záchytem ns-KT. ${ }^{46,47}$ Posledně jmenovaný ukazatel má však nízkou specificitu. ${ }^{3}$ Přestože u významné části DKMP je pravděpodobný genetický podklad (s předpokládaným autosomálně dominantním přenosem), $v$ klinické praxi zatím genetická diagnostika nemá dopad pro rozhodování o další léčbě.

$\mathrm{K}$ potlačení výskytu komorové ektopie u DKMP je možno podávat amiodaron. $U$ pacientů $s$ výrazně vyšším rizikem náhlé srdeční smrti je indikace $\mathrm{k}$ implantaci ICD.

$\mathrm{V}$ rámci sekundární prevence náhlé srdeční smrti je indikace léčby $\mathrm{ICD} v$ indikační tř́dě $\mathrm{I}$. $\mathrm{V}$ rámci primárně preventivní indikace ICD u DKMP je obecně akceptována indikace, vyjádřená v tabulce 3 .

Tyto závěry o indikaci ICD v rámci primární prevence náhlé srdeční smrti se u ICHS a u neischemické DKMP opírají o výsledky několika multicentrických prospektivních randomizovaných studií s ICD - MADIT, MUSTT, MADIT II, SCD-HeFT - a byly opakovaně komentovány $\mathrm{v}$ citovaných doporučeních pro léčbu $\mathrm{ICD}^{1-3}$ a budou ještě zmíněny v dalším textu.

\subsection{Ostatní - méně časté - kardiomyopatie}

Rovněž u ostatních diagnostických jednotek platí, že hlavním rizikovým faktorem, který představuje indikaci $\mathrm{k}$ léčbě ICD, je výskyt s-KT či dokonce oběhové zástavy. Další riziková stratifikace má u jednotlivých diagnóz určitá specifika, která jsou stručně shrnuta v následujícím textu, který se týká indikací a výběru léčby.

Bylo již uvedeno výše, že př́nos elektrofyziologického testování u pacientů s neischemickou kardiomyopatií ve srovnání s tímto testem u koronární nemoci je podstatně nižší. U pacientů s hypertrofii levé komory je indukovatelnost s-KT u pacientů s ns-KT mezi $40-75 \%$, ale ve většině př́ipadů je vyvolána spiše polymorfní komorová tachykardie. Klinický význam tohoto nálezu není př́liš jasný,48 a pro výběr léčby není výsledek tohoto testu rozhodující. ${ }^{3}$

\subsubsection{Hypertrofická kardiomyopatie}

U hypertrofické kardiomyopatie má záchyt $n s-K T$ z hlediska posouzení rizika náhlé srdeční smrti určitý prognostický význam. ${ }^{49-52}$ Např́klad ve studii McKenny bylo ukázáno, že při této diagnóze a př́tomnosti ns-KT byla roční mortalita náhlou smrtí $8-10 \%$ ve srovnání s pacienty bez ns-KT, jejichž jednoroční mortalita $\mathrm{z}$ důvodu náhlé srdeční smrti byla $1 \% .{ }^{51}$ Zejména záchyt ns-KT během zátěžového testu EKG znamená výrazně vyšší riziko náhlé srdeční smrti (relativní riziko 3,14). ${ }^{52} \mathrm{~V}$ rizikové stratifikaci je dáván důraz též na dalši ukazatele a symptomy. Dle předchozích materiálů jsou definována tzv. velká riziková kritéria a méně významná riziková kritéria (tabulka 4).2,3,49,50

$\mathrm{V}$ rámci primární profylaxe náhlé srdeční smrti jsou $\mathrm{k}$ léčbě ICD indikováni pacienti s hypertrofickou kardiomyopatií, kteří mají jeden či více větších rizikových faktorů (indikační třída IIa, úroveň důkazů C). ${ }^{1}$

\subsubsection{Arytmogenní kardiomyopatie}

Diagnóza dalšího typu familiální KMP, tzv. arytmogenní dysplazie pravé komory (ARVD) či arytmogenní kardiomyopatie (AKMP) bývá obtížnější u méně zřetelných forem. Onemocnění je podmíněno mutacemi genů, určujících - mimo jiné - proteiny desmosomů (desmoplakin, plakoglobin aj.), které se podílejí na buněčných spojeních. Diagnóza AKMP se opírá o př́tomnost dvou tzv. velkých kritérií (jako je vý-

Tabulka 4 Rizikové faktory u hypertrofické kardiomyopatie

\begin{tabular}{|c|c|}
\hline Velké rizikové faktory & Možné rizikové faktory \\
\hline $\begin{array}{l}\text { - Oběhová zástava } \\
\text { - Spontánní s-KT } \\
\text { - RA: výskyt NSS } \\
\text { - Neobjasněná synkopa } \\
\text { - Tlouštka stěny LK > } 30 \text { mm } \\
\text { - Abnormální reakce TK } \\
\text { při zátěžovém testu } \\
\text { - Záchyt ns-KT }\end{array}$ & $\begin{array}{l}\text { - Fibrilace síní } \\
\text { - Známky ischemie myokardu } \\
\text { - Obstrukce výtokového traktu LK } \\
\text { - Riziková genová mutace } \\
\text { - Intenzivní fyzická zátěž } \\
\text { (vrcholový sport a další) }\end{array}$ \\
\hline \multicolumn{2}{|c|}{$\begin{array}{l}\text { LK - levá komora, NSS - náhlá srdeční smrt, ns-KT - nesetrvalá komorová } \\
\text { tachykardie, RA - rodinná anamnéza, s-KT - setrvalá komorová tachykardie, } \\
\text { TK - krevní tlak. }\end{array}$} \\
\hline Upraveno dle citace 3. & \\
\hline
\end{tabular}


razná dilatace či aneurysma pravé komory, vlna „epsilon“ či lokalizované prodloužení komplexu QRS > 110 ms na EKG ve svodech $\mathrm{z}$ pravého prekordia $\left(\mathrm{V}_{1}-\mathrm{V}_{3}\right)$, pozitivní rodinná anamnéza s prokázanou diagnózou AKMP, prokázané nahrazení myokardiální tkáně fibrózní a tukovou tkání na MR nebo histologicky (endomyokardiální biopsií), případně prítomnost jednoho velkého a dvou malých kritérií (jako je nález pozitivních pozdních komorových potenciálů, méně výrazná dilatace a dysfunkce pravé komory, negativní vlna $T$ ve svodech $V_{2}, V_{3}$ bez přítomnosti blokády pravého raménka aj.). ${ }^{53}$ Velmi senzitivní a specifický může být nález jizvy při elektroanatomickém mapování pravé komory. V rizikové stratifikaci AKMP má hlavní význam záchyt s-KT. Význam dalších ukazatelů v rizikové stratifikaci je u této diagnózy méně jasný. ${ }^{3,53-59}$ Programovaná stimulace komor má zde velmi omezený význam vzhledem k nízké pozitivní i negativní předpovědní hodnotě, které se pohybují kolem $50 \%{ }^{53,54}$ Rizikovým faktorem je nejspíše výrazná dilatace pravé komory a také současné postižení levé komory. ${ }^{54,58,59}$

$\mathrm{V}$ rámci primární profylaxe náhlé srdeční smrti jsou k léčbě ICD indikováni pacienti s AKMP, kteří mají jeden či více velkých rizikových faktorů (indikační třída IIa, úroveň důkazů C). ${ }^{1,3}$

\subsubsection{Non-kompaktní kardiomyopatie}

Diagnózou non-kompaktní kardiomyopatie (původním názvem „left ventricular non-compaction“, LVNC) je označován stav, kdy je přítomna nekompaktnost vnitřní části myokardu levé komory. Toto strukturální postižení je charakterizováno mohutnou trabekularizací části stěny levé komory s hlubokými recesy mezi trabekulami (proto též dřívější název spongiózní KMP). Obvykle je postižena hrotová část, spodní a zadní a laterální stěna apikálních dvou třetin levé komory a strukturální změna je spojena s dysfunkcí postižených segmentů s postupnou progresí sférické remodelace levé komory. Histologicky je též výraznější fibróza v postižené části myokardu, a to může přispívat ke vzniku komorové tachykardie na podkladě arytmogenního mechanismu reentry. Na EKG je pomalá progrese amplitudy r v hrudních svodech, obraz blokády levého Tawarova raménka a repolarizační změny s inverzí vlny T. U dostatečně morfologicky vyjádřených forem této KMP je echokardiografický nález a nález při vyšetření MR diagnostický.

Podkladem onemocnění je nejspíše hereditární porucha organogeneze srdeční svaloviny v průběhu fetálního vývoje. Nejspíše je to způsobeno změnou genů kódujících sarkomerické proteiny a lamin AC; data v tomto směru jsou však zatím sporadická. $\mathrm{V}$ pediatrické populaci je to třetí nejčastější KMP (po dilatační a hypertrofické KMP) ${ }^{60}$ Komorovou tachykardii lze zachytit u $50 \%$ dospělé populace, mortalita je téměř $50 \%$ při 5-6letém sledování, je u ní vysoký (zhruba 50\%) podíl náhlé srdeční smrti. ${ }^{61-63}$ Léčba je v zásadě stejná jako u dilatační KMP. U pacientů s funkční třídou NYHA I-II vzhledem ke zvýšenému riziku arytmogeneze u této diagnózy - při záchytu komorové tachykardie či při výskytu závažných symptomů budících podezření na výskyt komorové tachykardie (případně s indukovatelnou komorovou tachykardií při elektrofyziologickém testování) - je indikace k implantaci ICD. ${ }^{1,3} \mathrm{~S}$ ohledem na vyšší výskyt supraventrikulárních tachyarytmií u této nemoci je vhodné implantovat dvoudutinový ICD. ${ }^{62} \mathrm{U}$ pacientů s funkční třídou NYHA III-IV s výskytem blokády levého Tawarova raménka je zvažována implantace ICD s biventrikulární stimulací.

\subsubsection{Restriktivní kardiomyopatie}

Restriktivní kardiomyopatie je charakterizována restriktivní poruchou plnění levé komory, způsobené zvýšenou tuhostí stěn komory v důsledku extracelulárních i intracelulárních změn v myokardu. Onemocnění, vedoucí k restrikci plnění levé komory, můžeme rozdělit na infiltrativní a střádavé kardiomyopatie a na choroby neinfiltrativní.

Hlavními diagnostickými jednotkami ve skupině infiltrativních kardiomyopatií jsou amyloidóza, sarkoidóza, hemochromatóza a Fabryho nemoc.,64

Obecně lze shrnout, že léčba komorových arytmií je u těchto poruch obdobná jako u jiných kardiomyopatií s tím rozdílem, že není indikována implantace ICD v rámci primární profylaxe náhlé srdeční smrti. ${ }^{3}$

Navíc klinický průběh těchto nosologických jednotek vykazuje určitá specifika, $\mathrm{z}$ nichž alespoň některá zmiňujeme v dalším textu.

Amyloidóza je onemocnění charakterizované extracelulárním ukládáním specifické bílkoviny (amyloidu) v různých orgánech. Srdeční postižení je zejména u subtypu AL, kde hlavní součástí amyloidních depozit jsou lehké řetězce imunoglobulinů nebo jejich fragmenty. Depozita amyloidu bývají provázena fibrózou převodního srdečního systému. Kardiální postižení při amyloidóze se manifestuje jako restriktivní kardiomyopatie - srdečním selháváním, poruchou diastolické funkce levé komory, poruchami srdečního rytmu. Na EKG je nižší voltáž komplexu QRS ve všech svodech, při echokardiografickém vyšetření je patrno ztluštění stěn levé komory a známky diastolické dysfunkce. Diagnóza může být podpořena též vyšetřením MR a důležitý je histologický nález při endomyokardiální biopsii případně biopsii z jiné tkáně. Při pozitivním nálezu amyloidu je třeba doplnit typizaci imunohistochemicky či imunoelektromikroskopicky. ${ }^{64}$

Jednou z manifestací kardiálního postižení mohou být ns-KT i s-KT. ${ }^{3,65,66}$ Nález zvýšené hodnoty troponinu T, tlouštka stěny levé komory > $12 \mathrm{~mm}$, porucha nitrokomorového vedení a záchyt komorové tachykardie signalizují špatnou prognózu, medián přežívání je udáván kolem šesti měsíců. ${ }^{3,66}$ Komorová tachykardie při amyloidóze může skončit náhlou srdeční smrtí, pokud není rychle aplikována agresivní terapie. Vzhledem k prognostické závažnosti uvedeného postižení je možné při difuznějším postižení myokardu zvážit OTS, ale názory na vhodnost této léčby se výrazně liší. ICD může být indikován jako most k OTS, pokud je úvaha o transplantaci srdce akceptována, ${ }^{3}$ avšak ICD jako samostatná, konečná léčba neovlivní zřetelněji 
přežívání pacientů se systémovou AL amyloidózou s kardiálním postižením.

Sarkoidóza je multisystémové granulomatózní onemocnění nejasné etiologie, které $\mathrm{v}$ menším procentu prrípadů může postihovat i srdce. Manifestace kardiálního postižení může být v podobě poruchy vedení vzruchu př̀ prítomnosti granulomů. V léčbě mají dominantní postavení kortikosteroidy, při trvající bradyarytmické poruše je indikace $\mathrm{k}$ trvalé kardiostimulaci. U části pacientů se mohou vyskytovat i klinicky významnější komorové arytmie. ${ }^{67}$ Medikamentózní léčba bývá málo účinná a u dokumentované komorové tachykardie připadá $\mathrm{v}$ úvahu implantace kardioverteru-defibrilátoru. , $^{3,68,69}$

Hemochromatóza je charakterizována jako poškození orgánů (včetně srdce) ukládáním železa. Nejčastější forma je hereditární - autosomálně recesivní onemocnění způsobené změnou genu kódujícího regulační protein, který ovlivňuje vychytávání železa ve střevech a játrech. Získaná sekundární hemochromatóza vzniká při poruchách erytropoézy nebo $\mathrm{v}$ důsledku nadměrného př́ímu železa. V srdci se železo ukládá v sarkoplazmatickém retikulu kardiomyocytů - výrazněji $\mathrm{v}$ komorovém myokardu. Př́má toxicita volných iontů železa způsobuje $\mathrm{v}$ srdci úbytek myocytů a fibrózu myokardu. ${ }^{64}$ Klinické příznaky zahrnují známky srdečního selhávání a známky poškození dalších orgánů (jaterní cirhóza, diabetes aj.). Na EKG jsou nespecifické repolarizační změny, echokardiografie ukazuje dilataci a ztluštění stěny levé komory a nejprve diastolickou, pak i systolickou dysfunkci levé komory. Časnější stadia postižení myokardu může diagnostikovat magnetická rezonance. Laboratorně můžeme zachytit zvýšené sérové koncentrace feritinu a zvýšenou saturaci transferinu. ${ }^{64}$ Bývají zachyceny poruchy síňokomorového převodu, komorové arytmie až náhlá srdeční smrt. ${ }^{69}$ Při manifestní setrvalé komorové tachyarytmii je indikováno zajištění pacienta ICD.

Fabryho nemoc je geneticky podmíněná enzymopatie, způsobená deficitem lysosomálního enzymu a-galaktosidázy A, která štěpí neutrální glykolipidy.,70 Manifestuje se zřetelně nejčastěji $\mathrm{v}$ dospělosti, ale první prríznaky počínají v adolescenci. Fabryho nemoc patří mezi tzv. střádavá onemocnění, střádání glykosfingolipidů probíhá v lysosomech v buňkách cévní stěny, v glomerulárních a tubulárních buňkách ledvin i v kardiomyocytech. Mikroangiopatie způsobuje charakteristické kožní léze angiokeratomy. U mužů (hemizygotů) dominuje postižení ledvin a myokardu (rázu restriktivní nebo hypertrofické $\mathrm{KMP}$ ), u žen (heterozygotních) může být široké spektrum klinických manifestací. ${ }^{70-72}$ Je udáváno, že prevalence Fabryho KMP je u 3-6 \% mužů s jinak nevysvětlenou hypertrofií levé komory. Výskyt komorové tachykardie či náhlé srdeční smrti je u této diagnózy řídkým jevem. ${ }^{3}$ Diagnózu prokáže deficit a-galaktosidázy, vylučování kritických glykolipidů močí, bioptický elektronmikroskopický průkaz př́slušného střádání, případně genetická diagnostika mutace $\mathrm{v}$ zodpovědném genu. Léčba je obvyklá jako u kardiální a renální insuficience z jiných příčin, nově jsou ověřovány postupy - substituce enzymu k ovlivnění dané enzymopatie. ${ }^{72}$ Léčba arytmií je obdobná jako u jiných kardiomyopatií. ${ }^{3,70}$

Neinfiltrativní restriktivní kardiomyopatie. V této skupině kardiomyopatií jsou známy především dvě následující diagnostické jednotky:

Idiopatická restriktivní kardiomyopatie je poměrně vzácné onemocnění u dětí a dospívajících. Pacient má normální velikost levé komory a nález zvýšených plnicích tlaků v srdečních komorách. Nemá infiltrativní změny v myokardu, ale je výrazná intersticiální fibróza a hypertrofie kardiomyocytů. Patogeneze tohoto onemocnění zůstává nejasná. Endomyokardiální biopsie neprokazuje specifické infiltrativní příčiny poruchy funkce myokardu. Obvyklým projevem je srdeční selhání nejčastěji mezi 20.-30. rokem věku, onemocnění je provázeno poruchami srdečního rytmu. Léčba arytmií a srdečního selhávání je obdobná jako u jiných kardiomyopatií, u refrakterního srdečního selhání je indikována transplantace srdce. ${ }^{3,64}$

Endomyokardiální fibrózy lze dle jejich původu třídit na tropické, hypereosinofilní a iatrogenní. Posledně jmenovaná skupina je podmíněna dlouhodobějším podáváním methylsergidu (antimigrenózní přípravek), anabolických kortikosteroidů nebo adriamycinu.

Prvně jmenovaná skupina se vyskytuje v rovníkových zemích a představuje významné procento srdečních selhání a kardiovaskulární mortality. V mírném pásmu se vyskytuje hypereosinofilní endomyokardiální fibróza. Jde o primární restriktivní kardiomyopatii s nejasným patofyziologickým podkladem. Je známo, že stavy spojené s déle (týdny až měsíce) trvající hypereosinofilií mohou vést $\mathrm{k}$ poškození myokardu v důsledku stimulace fibroblastů. Důsledkem je fibróza endokardu s převažujícím postižením hrotu, vtokové části komor a závěsného aparátu atrioventrikulárních chlopní. Klinickým projevem je srdeční selhání, mohou být arytmické poruchy. Léčba je cílena na primární příčinu hypereosinofilie, jinak odpovídá standardní léčbě srdečního selhání, případně je cílena na korekci chlopňových regurgitací a na standardní léčbu arytmií.

\subsubsection{Druhotné kardiomyopatie (druhotné postižení myokardu)}

Do této skupiny je možno zařadit např́klad alkoholickou KMP či KMP při jiných toxických postiženích (včetně KMP po chemoterapii, jako je antracyklinová KMP), diabetickou KMP, KMP při svalových dystrofiích aj. Jen stručně zmíníme posledně jmenovanou KMP, která může provázet vzácné, geneticky podmíněné primární poruchy skeletálního svalstva. Patří sem Duchenneova a Beckerova svalová dystrofie, u nichž je geneticky podmíněna mutace dystrofinu, přenos je recesivní, vázaný na chromosom $\mathrm{X}$. U těchto forem svalové dystrofie i u další formy Emeryho-Dreifussovy svalové dystrofie je srdečním projevem dilatační KMP, která může být provázena různými arytmiemi včetně komorové tachykardie. Pokud je př́tomno chronické srdeční selhání, léčba se neliší od standardní léčby při chronické DKMP. V rámci 
sekundární prevence náhlé srdeční smrti je indikována léčba ICD. ${ }^{3,73,74}$ Pozornost je věnována ovlivnění primárního onemocnění. U posledně jmenované svalové dystrofie (Emeryho-Dreifussovy), pokud je prítomna porucha převodního systému a prokázána genová mutace kódující lamin $\mathrm{A} / \mathrm{C}$, je dle klinických zkušeností vysoké riziko brzké manifestace komorové tachykardie a je primárně profylakticky indikována implantace ICD. ${ }^{75}$

\subsection{Riziková stratifikace u hereditárních arytmických syndromů}

Do této skupiny kardiálního postižení jsou řazeny geneticky podmíněné poruchy funkce některých iontových kanálů, zejména ovlivňujících repolarizační fázi srdečního cyklu, které mají arytmický potenciál, ohrožující pacienta výskytem komorových arytmií až náhlé srdeční smrti.

\subsubsection{Syndrom dlouhého QT}

Kongenitální syndrom dlouhého QT (LQTS) je nejlépe probádanou „primární elektrickou“ srdeční poruchou. ${ }^{3,76,77}$ Dosud bylo identifikováno více než 250 mutací na 12 genech a dle této diagnostiky jsou rozlišovány jednotlivé formy LQTS 1-12 a dvě formy spojené s vrozenou hluchotou a označované jako Jervellův-Langeův-Nielsenův syndrom. ${ }^{78}$ Přes tento pokrok v diagnostice $u$ více než jedné čtvrtiny pacientů s LQTS zatím nebyla nalezena genetická abnormalita a lze očekávat, že budou objeveny další genové mutace zodpovědné za patologický průběh srdeční repolarizace a zvýšené riziko náhlé srdeční smrti. Je intenzivně studován vztah mezi genotypem a fenotypem u LQTS. Zvýšené riziko náhlé srdeční smrti představuje nález QTc > 550-600 ms, geneticky diagnostikovaný LQTS 3 a výskyt synkopy $v$ dětském věku. ${ }^{3,77-81}$ Dle dosavadních pozorování je udávána jednoroční mortalita $\mathrm{z}$ důvodu náhlé srdeční smrti u tří nejznámějších genotypů LQTS následovně: ${ }^{81}$

> LQT1: $0,3 \% /$ rok (muži $0,33 \%$, ženy $0,28 \%$ )

LQT2: $0,6 \% /$ rok (muži 0,46 \%, ženy 0,82 \%)

>QT3: $0,56 \% /$ rok (muži 0,96 \%, ženy 0,30\%)

Data o přínosu léčby ICD u LQTS jsou omezená. Výsledky dosavadních srovnávacích studií ukazují zřetelný přínos léčby ICD na snížení mortality u pacientů s anamnézou oběhové zástavy či synkopy při diagnóze LQTS. ${ }^{82} \mathrm{U}$ těchto stavů - tedy $\mathrm{v}$ podstatě v rámci sekundárně preventivní indikace - je plně opodstatněná léčba ICD. ${ }^{1,3,81}$

Dosavadní data z registrů LQTS nepodporují předchozí doporučení k primárně profylaktické implantaci ICD (v indikační třídě IIb s úrovní důkazů $\mathrm{C}$ ) u asymptomatických pacientů s genotypem LQT2 a LQT3 ${ }^{81} \mathrm{U}$ těchto pacientů je preferována léčba beta-blokátorem, př́padně v kombinaci s trvalou (přednostně síňovou) stimulací u pacientů s významnější bradykardií. ${ }^{1-3}$ Léčbu ICD v rámci primární prevence je možno zvážit u pacientů s rizikovějším klinickým či genotypickým profilem, u nichž je horší adherence k léčbě beta-blokátorem a k dodržování určitých režimových opatření.

\subsubsection{Syndrom krátkého QT}

Syndrom krátkého QT (SQTS) byl popsán poměrně nedávno. ${ }^{83}$ Je to další syndrom, spojený s výskytem komorových arytmií a náhlé srdeční smrti bez známek strukturálního srdečního postižení. Jeho charakteristickým znakem je zřetelně kratší interval QT (orientačně < 0,34 s), než odpovídá průměrné normální hodnotě. ${ }^{3,83}$ Pacienti s tímto postižením, které bývá familiární, mají zkrácenou efektivní refrakteritu komorového i síňového myokardu a zvýšenou vulnerabilitu k fibrilaci síní i komor. Podkladem je genetická mutace, podmiňující zvýšenou funkci vyrovnávajícího proudu draslíkových iontů $\mathrm{z}$ buňky $\left(\mathrm{I}_{\mathrm{Kr}}\right.$, případně $\left.\mathrm{i} \mathrm{I}_{\mathrm{Ks}}\right) .^{3,84,85}$ To vede ke zkrácení trvání akčního potenciálu a prohloubení heterogenity repolarizace komorového (i síňového myokardu), což může vyústit až ve fibrilaci komor. Jako závažný rizikový faktor je bráno výrazné zkrácení QTc $(<0,3$ s), záchyt s-KA u pacienta či výskyt náhlé srdeční smrti v postižené rodině. ${ }^{85}$

$\mathrm{U}$ pacientů s tímto syndromem s dokumentovanou komorovou tachykardií je indikována implantace ICD. ${ }^{3}$

$\mathrm{U}$ pacientů s detekovanou mutací genu $\mathrm{KCNH} 2$ je možno zvažovat léčbu antiarytmikem třídy IA (chinidinem), nicméně dlouhodobější protektivní efekt na výskyt komorových arytmií není prokázán. ${ }^{3}$

\subsubsection{Syndrom Brugadových}

Syndrom Brugadových je další klinickou jednotkou s výskytem maligních komorových arytmií na podkladě poruchy repolarizace bez prokazatelného strukturálního srdečního postižení. ${ }^{86}$

Uvedená porucha s arytmickým potenciálem mívá familiární ráz a nejspíše jde o autosomálně dominantní přenos s inkompletní penetrací. Dosud většina identifikovaných genových mutací u této diagnostické jednotky se týkala genu SCN5A, kódujícího funkci podjednotky voltážově řízeného sodíkového kanálu. ${ }^{78,81} \mathrm{Na}$ EKG je obraz blokády pravého Tawarova raménka s výraznou elevací úseku ST (s výraznou vlnou J) v hrudních svodech $\mathrm{V}_{1}-\mathrm{V}_{3}$. Tento nález může být intermitentní a může se manifestovat až po intravenózní aplikaci antiarytmika I. třídy (např. ajmalinu $1 \mathrm{mg} / \mathrm{kg}$ hmotnosti) nebo beta-blokátoru či při febrilním stavu nebo po alkoholové intoxikaci. ${ }^{87}$ Typicky se vyskytují komorové extrasystoly s krátkým vazebným intervalem a paroxysmy polymorfní komorové tachykardie či fibrilace komor. Při záchytu maligní komorové arytmie nebo při výskytu synkopy u spontánního typického EKG obrazu tohoto syndromu je indikována implantace ICD. ${ }^{3,88,89}$ Pozitivní rodinná anamnéza výskytu náhlé srdeční smrti sama o sobě nepředstavuje indikaci k ICD u asymptomatického pacienta bez spontánní EKG manifestace typické pro zmíněný syndrom. ${ }^{81}$ Data z velkého mezinárodního registru více než 1000 pacientů $s$ uvedenou diagnózou ukazují, že při střednědobém sledování je u asymptomatických pacientů poměrně nízké riziko náhlé srdeční smrti. ${ }^{89}$

\subsubsection{Syndrom předčasné komorové repolarizace}

Syndrom předčasné komorové repolarizace patři do skupiny poruch srdeční repolarizace. Je charakterizován elevací 
bodu J (spojení QRS-ST) $\geq 1 \mathrm{~mm}$ na elektrokardiogramu ve svodech jiných než $\mathrm{V}_{1}-\mathrm{V}_{3}$, což může být provázeno zvýšenou vulnerabilitou k maligním komorových tachyarytmiím včetně fibrilace komor. ${ }^{90,91}$ Popsaná abnormalita EKG s prevalencí 1-3 \% u dospělých osob byla dříve považována za benigní nález, nicméně nedávno publikované práce upozorňují na vyšší riziko náhlé srdeční smrti u pacientů s tímto nálezem..$^{90-94}$ Retrospektivní analýza křivek EKG a klinického stavu u téměř 11000 pacientů středního věku ukázala zvýšené riziko výskytu náhlé srdeční smrti u pacientů s elevací bodu J (v podobě obloučku či zálomu na kmitu S) $\geq 2 \mathrm{~mm}$ ve spodních či laterálních svodech EKG. Těchto pacientů v uvedeném neselektovaném souboru s průměrným věkem $44 \pm 8$ roků bylo $0,1 \%$. Jejich relativní riziko kardiální mortality při delším průměrném sledování (30 \pm 11 roků) bylo 2,98 (95 \% interval spolehlivosti $1,85-4,92)(\mathrm{p}<0,001)$ a obdobné bylo i relativní riziko náhlé arytmické smrti (2,92; s rozmezím 1,45-5,89, $\mathrm{p}<0,001) .{ }^{91}$ Další práce ukázala častější výskyt nálezu předčasné repolarizace s elevací bodu $\mathrm{J} \geq 1 \mathrm{~mm}$ ve spodních (II, III, aVF) či laterálních (I, aVL, $\mathrm{V}_{4}-\mathrm{V}_{6}$ ) svodech EKG (ve $31 \%$ ) v souboru 206 pacientů po úspěšné resuscitaci pro tzv. idiopatickou fibrilaci komor. ${ }^{92}$ V̌̌ichni pacienti byli dále zajištění léčbou ICD. Během sledování (medián 50 měsíců) byl výskyt recidivy komorových arytmií - převážně fibrilace komor - u 41 \% z nich. Rovněž analýzy nálezů EKG u sportovců resuscitovaných pro náhlou oběhovou zástavu ukázaly vyšší výskyt předčasné komorové repolarizace (28,6 \%), bez známek strukturálního srdečního postižení - ve srovnání s kontrolním souborem $(\mathrm{p}=0,007) \cdot{ }^{93}$

Pravděpodobným podkladem předčasné repolarizace je abnormální funkce některých draslíkových iontových kanálů (zejména $\mathrm{I}_{\mathrm{to}}$ ), podílejících se na průběhu komorové repolarizace. Výsledkem může být zvýraznění disperze trvání akčního potenciálu $\mathrm{v}$ myocytech různých vrstev komorového myokardu. ${ }^{94,95}$

Zvláštní pozornost je věnována výskytu EKG předčasné repolarizace u pacientů s manifestní koronární nemocí, kde tento nález představuje zvýšené riziko výskytu komorových arytmií bez ohledu na systolickou funkci levé komory. ${ }^{96}$ Poruchy komorové repolarizace v průběhu hojení infarktu myokardu a u chronických forem ICHS jsou cílem zájmu stratifikace rizika náhlé srdeční smrti. Indikace k léčbě ICD je analogická jako u syndromu Brugadových - v rámci sekundární prevence náhlé srdeční smrti je v indikační třídě I, u pacientů se synkopou nebo u pacientů s dokumentovanou komorovou tachykardií bez synkopy - je uvedená léčba v indikační třídě IIa (úroveň důkazů C).

\subsubsection{Katecholaminy indukovaná polymorfní komorová tachykardie}

Katecholaminy indukovaná polymorfní komorová tachykardie (KPKT) představuje klinicky i geneticky heterogenní onemocnění. , $^{38,81,97-100}$ Patří do spektra hereditárních arytmických syndromů, bez zjevného strukturálního srdečního postižení. Klinicky se manifestuje nejčastěji $\mathrm{v}$ dětském věku, typicky synkopou či zachycenou komo- rovou tachykardií při zátěži. Diagnostická je bidirekční komorová tachykardie, která může degenerovat do fibrilace komor. Až 30 \% nemocných s touto diagnózou umírá z důvodu náhlé srdeční smrti ve věku do 30 let. Klidové EKG je normální, pro diagnostiku je důležitý zátěžový EKG test. Mutační analýza souvisejících genů nachází asi u $50 \%$ postižených mutaci genu pro ryanodinový receptor (RyR2), což je vápníkový kanál sarkoplazmatického retikula kardiomyocytu, který se podílí na intracelulárním přenosu vápníku. ${ }^{78,98,100}$ Ve sporadických případech je mutace genu pro calsequestrin, který je součástí bílkovinného komplexu ve vazbě na ryanodinový receptor. Jak již bylo uvedeno výše, charakteristický je výskyt závažné komorové arytmie při fyzické zátěži či psychickém stresu u osob bez prokazatelného organického srdečního postižení. Indukovatelnost s-KT při PSK není považována za významnější prediktor rizika náhlé srdeční smrti a větší význam je dle konsensu expertů přikládán záchytu $n s-K T$ či $s-K T$ př $i$ zátěžovém EKG testu či při Holterově monitorování EKG. ${ }^{3}$ $\mathrm{V}$ rámci diagnostiky již lze $\mathrm{v}$ současnosti v ČR zajistit provedení analýzy genu pro ryanodinový receptor. ${ }^{100}$ V léčbě stojí v popředí beta-blokátory. ICD je indikován jen $\mathrm{v}$ rámci sekundární prevence náhlé srdeční smrti. ${ }^{3,98}$

Zvláštní variantou je polymorfní komorová tachykardie charakteru „torsade de pointes“ spouštěná komorovými extrasystolami s krátkým vazebným intervalem ( $\leq 250 \mathrm{~ms})$ „short-coupled variant of torsade de pointes" ${ }^{101}$ Arytmie se vyskytuje převážně u mladších jedinců a není spojena s nálezem prodlouženého QT intervalu na EKG. Bývá přítomna pozitivní rodinná anamnéza výskytu náhlé srdeční smrti, a lze tedy předpokládat genetický podklad této jednotky. Vzhledem k vysokému riziku náhlé srdeční smrti je u této diagnózy indikována léčba ICD. ${ }^{3}$

Klinické nálezy a doporučená vyšetření pro stratifikaci rizika náhlé srdeční smrti u jednotlivých diagnostických jednotek uvádí schematicky tabulka 5 .

Indikace léčebných postupů u komorových arytmií u jednotlivých diagnostických jednotek v rámci sekundární prevence náhlé srdeční smrti ukazuje schematicky tabulka 6.

Indikace léčebných postupů u komorových arytmií u jednotlivých diagnostických jednotek v rámci primární prevence náhlé srdeční smrti popisuje schematicky tabulka 7.

\subsection{Riziková stratifikace u dalších klinických stavů s výskytem komorových arytmií}

\subsubsection{Stavy po chirurgické korekci vrozených srdečních vad}

Komorové tachykardie po chirurgické korekci vrozených srdečních vad představují specifickou skupinu. Vyskytují se po výkonech, zahrnujících ventrikulotomii (typicky bývají po operaci Fallotovy tetralogie, defektu komorového septa a po operaci stenózy plicnice). Většinou jde o komorovou tachykardii typu „makro-reentry“, při níž vzruch krouží kolem pooperační jizvy či kolem záplaty. Jsou určité ukazatele (např̀ výrazné pozdní komorové potenciály), svědčící pro vyšší riziko s-KT u pacientů po operaci vrozené srdeční 
Tabulka 5 Klinické nálezy a doporučená vyšetření pro rizikovou stratifikaci pacientů $z$ hlediska jejich ohrožení NSS

\begin{tabular}{|c|c|c|c|}
\hline Trída I & \multicolumn{3}{|c|}{$\begin{array}{l}\text { Je jasná evidence a všeobecný souhlas, že použití daného } \\
\text { parametru rizikové stratifikace je užitečné a efektivní }\end{array}$} \\
\hline Tř́da lla & \multicolumn{3}{|c|}{$\begin{array}{l}\text { Evidence o užitečnosti daného parametru rizikové } \\
\text { stratifikace není jednoznačná, avšak data ve prospěch } \\
\text { významu tohoto parametru zřetelně převažují }\end{array}$} \\
\hline Trída llb & \multicolumn{3}{|c|}{$\begin{array}{l}\text { Obdobný závěr jako u lla s tím, že evidence o užitečnosti } \\
\text { daného parametru je méně přesvědčivá }\end{array}$} \\
\hline \multicolumn{2}{|c|}{ Indikační třída: I } & Ila & Ilb \\
\hline \multirow[t]{4}{*}{ ICHS, po IM } & $s-K T / K F$ & KES & LP \\
\hline & EFLK & $\mathrm{ns}-\mathrm{KT}$ & PES \\
\hline & HRV/BRS & klidová SF & \\
\hline & MTWA & & \\
\hline \multirow[t]{5}{*}{ HKMP } & $s-K T / K F$ & RA: NSS & Rizikový genotyp \\
\hline & Oběhová zástava & Synkopa & \\
\hline & & Septum $\geq 3 c$ & \\
\hline & & $\mathrm{ns}-\mathrm{KT}$ & \\
\hline & & $\begin{array}{l}\text { Hypotenze pi } \\
\text { zátěžovém te }\end{array}$ & \\
\hline \multirow[t]{2}{*}{ DKMP } & $\mathrm{s}-\mathrm{KT} / \mathrm{KF}$ & Synkopa & EFLK \\
\hline & & & ns-KT \\
\hline \multirow[t]{3}{*}{ ARVD } & - & $\begin{array}{l}\text { Oběhová } \\
\text { zástava }\end{array}$ & PES \\
\hline & & Dilatace PK & Synkopa \\
\hline & & $\begin{array}{l}\text { Současné } \\
\text { postižení LK }\end{array}$ & $\begin{array}{l}\text { Dysfunkce } \\
\text { PK }+ \text { LP }\end{array}$ \\
\hline \multirow[t]{3}{*}{ LQTS } & s-KT/KF (TDP) & QTc $>0,6 s$ & RA: NSS \\
\hline & Oběhová zástava & & \\
\hline & Synkopa & & \\
\hline
\end{tabular}

ARVD - arytmogenní dysplazie pravé komory (kardiomyopatie PK), BRS - senzitivita baroreflexu, DKMP - dilatační kardiomyopatie, EFLK - ejekční frakce levé komory, HKMP - hypertrofická kardiomyopatie, HRV - variabilita srdeční frekvence, ICHS - ischemická choroba srdeční, IM - infarkt myokardu, KES komorová extrasystolie, KF - fibrilace komor, LQTS - syndrom dlouhého QT, LP - komorové pozdní potenciály, MTWA - mikrovoltové kolísání („alternans") T-viny na EKG, nsKT - nesetrvalá komorová tachykardie, NSS - náhlá srdečni smrt, PES - programovaná stimulace komor, PK - pravá komora, RA - rodinná anamnéza, SF - srdeční frekvence, s-KT - setrvalá komorová tachykardie, TDP - komorová tachykardie typu torsade de pointes

Upraveno dle citace 3

vady. ${ }^{102} \mathrm{U}$ hemodynamicky tolerované s-KT stabilní morfologie bývá ověřován účinek antiarytmika a některé formy lze příznivě ovlivnit katetrizační ablací. ${ }^{4,103,104} \mathrm{U}$ závažných forem komorových arytmií a při jejich měnlivé morfologii je indikována léčba ICD. ${ }^{1-3}$

\subsubsection{Zánětlivá onemocnění myokardu}

Myokarditidy patří mezi významné přričiny náhlé srdeční smrti u mladých pacientů. Dle některých studií, opírajících se o sekční nálezy, byly známky myokarditidy prokázány až u 40-45\% př́padů náhlé srdeční smrti u mladých osob. ${ }^{3,104-107}$ Příčinou zánětu myokardu může být infekční agens (nejčastěji virová infekce, ale též bakteriální, mykotická, protozoální aj.), ale mohou to být i jiné vlivy
Tabulka 6 Indikace léčebných postupů v rámci sekundární

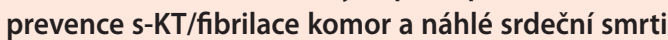
u jednotlivých diagnóz (jsou uvedeny indikační třídy l, lla, Ilb, v závorce je úroveň důkazů dle kritérií medicíny založené na důkazech

\begin{tabular}{|c|c|c|c|}
\hline \multicolumn{4}{|c|}{ Sekundární prevence (prevence recidivy s-KT/FK) } \\
\hline \multirow[t]{2}{*}{ Diagnóza } & \multicolumn{3}{|c|}{ Léčba dle indikační třídy } \\
\hline & I & Ila & llb \\
\hline ICHS, stav po IM & ICD (A) & $\begin{array}{l}\text { amiodaron, } \\
\text { beta-blokátory (C) }\end{array}$ & $\begin{array}{l}\text { RFA, chirurgická } \\
\text { ablace (C) }\end{array}$ \\
\hline HKMP & ICD (B) - & & \\
\hline DKMP & $\mathrm{ICD}(\mathrm{B})$ & \multicolumn{2}{|l|}{$\begin{array}{l}\text { amiodaron, } \\
\text { beta-blokátory (C) }\end{array}$} \\
\hline ARVD & $\mathrm{ICD}(\mathrm{B})$ & \multicolumn{2}{|l|}{-} \\
\hline LQTS & $\mathrm{ICD}(\mathrm{C})$ & & \\
\hline Brugada syndrom & $\mathrm{ICD}(\mathrm{B})$ & & \\
\hline CPVT & $\mathrm{ICD}(\mathrm{C})$ & \multicolumn{2}{|l|}{ beta-blokátory (C) } \\
\hline MVP & $\mathrm{ICD}(\mathrm{C})$ & & \\
\hline Aortální stenóza & $\mathrm{ICD}(\mathrm{C})$ & & \\
\hline $\begin{array}{l}\text { Synkopa (bez EKG), } \\
\text { indukovatelný s-KT/FK, } \\
\text { EFLK } \leq 40 \%\end{array}$ & ICD (B) & & \\
\hline $\begin{array}{l}\text { s-KT/KF bez struktu- } \\
\text { rálních onemocnění } \\
\text { myokardu }\end{array}$ & $\mathrm{ICD}(\mathrm{C})$ & & \\
\hline $\begin{array}{l}\text { ARVD - arytmogenní dys } \\
\text { techolaminy spouštěná p } \\
\text { kardiomyopatie, EFLK - e } \\
\text { diomyopatie, ICD - impla } \\
\text { choroba srdeční, IM - info } \\
\text { dlouhého QT, MVP - prol } \\
\text { s-KT - setrvalá komorová }\end{array}$ & $\begin{array}{l}\text { plazie prav } \\
\text { polymorfní } \\
\text { jekční frakc } \\
\text { intabilní ka } \\
\text { arkt myoka } \\
\text { laps mitrál }\end{array}$ & $\begin{array}{l}\text { komory (kardiomyopa } \\
\text { komorová tachykardie } \\
\text { elevé komory, HKMP- } \\
\text { rdioverter-defibrilátor, } \\
\text { du, KF- fibrilace komo } \\
\text { í chlopně, RFA - radio } \\
\text { lie }\end{array}$ & $\begin{array}{l}\text { atie PK), CPVT - ka- } \\
\text { e, DKMP - dilatační } \\
\text { - hypertrofická kar- } \\
\text { ICHS - ischemická } \\
\text { or, LQTS - syndrom } \\
\text { frekvenční ablace, }\end{array}$ \\
\hline
\end{tabular}

(chemické látky, toxiny, radiace aj.). ${ }^{3,108,109}$ Mimo jiné kardiální symptomy při myokarditidě se mohou vyskytnout i komorové arytmie, a jak již je zmíněno výše, i náhlá srdeční smrt. ${ }^{3,108}$

Tzv. lymeská karditida může být komplikací lymeské borreliózy. Bývá spíše provázena převodními poruchami. Výskyt komorové tachykardie při tomto postižení je vzácný. ${ }^{3,110}$

U akutních forem karditidy s výskytem komorové tachykardie je možno použít antiarytmikum, ICD v této situaci není indikován. ${ }^{3}$

Komorové tachykardie bývají častou přičinou náhlé srdeční smrti též u Chagasovy choroby, což je myokarditida způsobená prvoky rodu Trypanosoma. ${ }^{107,111}$ Hlavní endemickou oblastí výskytu Chagasovy choroby je Jižní a Střední Amerika. Komorová arytmie typicky vychází z okraje aneurysmatu hrotové oblasti komory a relativně častá bývá subepikardiální lokalizace reentry okruhu. Léčbou volby může být katetrizační ablace a při její neschůdnosti či při nedostatečném účinku lze indikovat ICD (při chronické formě onemocnění). ${ }^{112}$ Při selhání srdce u Chagasovy choroby lze zvážit ortotopickou transplantaci srdce (OTS). Příznivý účinek na komorové arytmie může mít i chronická léčba amiodaronem. ${ }^{3}$ 
Tabulka 7 Indikace léčebných postupů v rámci primární prevence s-KT/FK a náhlé srdeční smrti u jednotlivých diagnóz (jsou uvedeny indikační třídy I, lla, Ilb, v závorce je úroveň důkazů dle kritérií medicíny založené na důkazech)

Primární prevence (prevence první ataky s-KT/fibrilace komor, náhlé srdeční smrti)

\begin{tabular}{|c|c|c|c|}
\hline \multirow[t]{2}{*}{ Diagnóza } & \multicolumn{3}{|c|}{ Léčba dle indikační třídy } \\
\hline & I & Ila & Illb \\
\hline $\begin{array}{l}\text { ICHS, stav po IM, } \\
\text { MADIT I }\end{array}$ & $\begin{array}{l}\text { ICD }(A) \text {, } \\
\text { beta-blokátory }(A) \text {, } \\
\text { Inhibitory ACE }(A)\end{array}$ & & \\
\hline $\begin{array}{l}\text { ICHS, stav po IM, } \\
\text { MADIT II }\end{array}$ & $\begin{array}{l}\text { ICD }(A) \text {, inhibitory } \\
A C E \text {, beta-bloká- } \\
\text { tory }(A)\end{array}$ & & \\
\hline $\begin{array}{l}\text { ICHS, ns-KT, dobrá } \\
\text { funkce LK }\end{array}$ & & \multicolumn{2}{|c|}{$\begin{array}{l}\text { inhibitory ACE, } \\
\text { beta-blokátory (B) }\end{array}$} \\
\hline $\begin{array}{l}\text { CHSS, NYHA III-IV } \\
\text { (COMPANION) }\end{array}$ & & \multicolumn{2}{|l|}{ ICD-BiV (B) } \\
\hline $\begin{array}{l}\text { CHSS, NYHA } \\
\text { II, EFLK } \leq 35 \% \\
\text { (SCD-HeFT) }\end{array}$ & \multicolumn{3}{|l|}{$\operatorname{ICD}(\mathrm{A})$} \\
\hline $\begin{array}{l}\text { HKMP (rizikový } \\
\text { profil*) }\end{array}$ & & $\mathrm{ICD}(\mathrm{B})$ & $\begin{array}{l}\text { amiodaron } \\
\text { (B) }\end{array}$ \\
\hline $\begin{array}{l}\text { DKMP (ns-KT, } \\
\text { EFLK } \leq 35 \% \text { ) }\end{array}$ & $\operatorname{ICD}(\mathrm{A})$ & \multicolumn{2}{|l|}{$\begin{array}{l}\text { amiodaron, } \\
\text { beta-blokátory (B) }\end{array}$} \\
\hline ARVD & & $\operatorname{ICD}(C)$ & sotalol (C) \\
\hline LQTS & beta-blokátory (B) & $\mathrm{ICD}(\mathrm{C})$ & $\mathrm{PM}(\mathrm{C})$ \\
\hline $\begin{array}{l}\text { Brugada syndrom } \\
\text { (rizikový profil**) }\end{array}$ & $\mathrm{ICD}(\mathrm{B})$ & & \\
\hline $\begin{array}{l}\text { CPVT (rizikový } \\
\text { profil }^{* * *} \text { ) }\end{array}$ & - & $\begin{array}{l}\text { beta-blokátory } \\
\text { (C) }\end{array}$ & $\mathrm{ICD}(\mathrm{C})$ \\
\hline Aortální stenóza & $\operatorname{AVR}(B)$ & amiodaron $(\mathrm{C})$ & \\
\hline \multicolumn{4}{|c|}{$\begin{array}{l}\text { * Synkopa (bez dokumentace na EKG), ns-KT, pozitivní rodinná anamnéza } \\
\text { náhlé srdeční smrti } \\
\text { ** Synkopa, indukovatelná komorová tachykardie } \\
\text { ** Synkopa, pozitivní rodinná anamnéza náhlé srdeční smrti }\end{array}$} \\
\hline \multicolumn{4}{|c|}{$\begin{array}{l}\text { ARVD - arytmogenní dysplazie pravé komory (kardiomyopatie pravé } \\
\text { komory), AVR: náhrada aortální chlopně, CPVT - katecholaminy spouštěná } \\
\text { polymorfní komorová tachykardie, DKMP - dilatační kardiomyopatie, EFLK - } \\
\text { ejekční frakce levé komory, HKMP - hypertrofická kardiomyopatie, CHSS - } \\
\text { chronické srdeční selhání, ICD - implantabilní kardioverter-defibrilátor, } \\
\text { ICHS - ischemická choroba srdeční, IM - infarkt myokardu, LQTS - syndrom } \\
\text { dlouhého QT, LP - komorové pozdní potenciály, ns-KT - nesetrvalá komorová } \\
\text { tachykardie, PM - kardiostimulátor, s-KT - setrvalá komorová tachykardie }\end{array}$} \\
\hline
\end{tabular}

6.4.3 Systémová onemocnění a další chorobné stavy Systémová onemocnění a další chorobné stavy mohou být rovněž provázeny výskytem různých forem komorových arytmií. Sem můžeme řadit např́klad systémová onemocnění (sklerodermii, revmatoidní artritidu, systémový lupus erythematodes, systémové vaskulitidy aj.), endokrinní poruchy (thyreopatie, feochromocytom, primární aldosteronismus s iontovou dysbalancí, aj.), malnutriční stavy, pokročilé renální selhání atd. V těchto př́padech je zásadní ovlivnění základního chorobného procesu. Přehled léčby těchto nemocí je mimo rámec daného textu a tato specifická problematika je zde zmíněna jen okrajově. Léčba arytmií v těchto př́padech obvykle nemá specifické rysy, je obdobná jako u idiopatických kardiomyopatií a pod- statná je zde léčba základního kardiálního postižení.,113 Pokud není výskyt hemodynamicky závažné komorové tachykardie spojen $\mathrm{s}$ akutní fází průvodní myokarditidy či $s$ reverzibilní poruchou metabolismu nebo s intoxikací - je možná indikace léčby ICD - v indikační tř́ídě IIa (s úrovní důkazů C) a mělo by být přitom postupováno uvážlivě dle podrobného zhodnocení dosavadního vývoje onemocnění a př́padných limitací dané léčby u individuálního pacienta. $^{3}$

\subsubsection{Chronické srdeční selhání}

Chronické srdeční selhání (CHSS) při ischemické i neischemické kardiomyopatii představuje specifickou problematiku $\mathrm{v}$ léčbě komorových arytmií. Je známo, že u pacientů s CHSS, ve funkční tř́dě II (NYHA klasifikace), s ejekční frakcí levé komory $<30 \%$, je vyšší riziko náhlé srdeční smrti, která je hlavní př́čcinou mortality. Naopak u pacientů s CHSS ve funkční tř́idě III a IV je hlavní př́činou úmrtí mechanické srdeční selhání. ${ }^{114}$ Pozornost studií cílených na primární profylaxi náhlé srdeční smrti a na snížení kardiální mortality u pacientů s CHSS je proto zaměrena na prognostický dopad léčby ICD, CRT a př́padně obou těchto postupů, kombinovaných s tzv. optimální farmakoterapií.

Studie SCD-HeFT (Sudden Cardiac Death in Heart Failure Trial), v níž byli rovnoměrně zastoupeni pacienti $\mathrm{s}$ ischemickou i neischemickou kardiomyopatií, ukázala, že především u pacientů s funkční třídou II (NYHA) jednoduchý ICD (fungující jako „shock only“ př́istroj) výrazně snížil celkovou mortalitu ve srovnání s placebem a s amiodaronem (snížení relativního rizika o $46 \%$ ). ${ }^{115}$ Další velká studie COMPANION (Comparison of Medical Therapy, Pacing, and Defibrillation in Chronic Heart Failure) u pacientů s CHSS ve funkční třídě NYHA III a IV, s ejekční frakcí levé komory $\leq 35 \%$ a s rozšířeným QRS > $120 \mathrm{~ms}$, bez konvenční indikace $\mathrm{k}$ implantaci kardiostimulátoru či ICD byla ukončena předčasně, nebơ již po relativně krátkém sledování byl zaznamenán výrazně př́iznivý efekt kombinace resynchronizační terapie a ICD na snížení celkové mortality (o $36 \%$ ). ${ }^{116}$ Resynchronizační terapie se na tomto zlepšení přeživání podílí zhruba ze dvou třetin. ${ }^{116}$ Studie COMPANION je první velkou randomizovanou studií, která prokázala příznivý dopad resynchronizační terapie na snížení mortality. Je tak naznačen další nový trend léčby ke zlepšení prognózy pacientů s CHSS. Výsledky studie CARE-HF (Cardiac Resynchronisation in Heart Failure) potvrzují tento závěr. ${ }^{117}$ Rovněž výsledky nedávno publikované studie MADIT-CRT potvrdily př́znivý efekt kombinované léčby ICD se srdeční resynchronizační léčbou oproti samotnému ICD na výskyt závažných oběhových př́hod na podkladě srdečního selhání u pacientů s CHSS ve funkční tř́dě NYHA II (či dokonce I) s EFLK $\leq 30 \%$, se širším komplexem $Q R S \geq 130 \mathrm{~ms} .{ }^{118}$ Relativní riziko pro primární výsledný ukazatel bylo 0,66 pro léčbu ICD-CRT $(\mathrm{p}=0,001)$. Následná subanalýza však ukázala, že nebyl zaznamenán přínos $\mathrm{z}$ této léčby u pacientů se širším 
komplexem QRS, které mělo jinou charakteristiku než blokáda levého Tawarova raménka. ${ }^{119}$

Současné indikace hlavních postupů léčby komorových arytmií jsou shrnuty v tabulce 6 .

\subsubsection{Stavy po ortotopické transplantaci srdce, rejekce štěpu}

U pacientů po ortotopické transplantaci srdce (OTS) se mohou vyskytovat kromě bradyarytmických poruch a sínových arytmií také různé komorové arytmie. Mohou se uplatnit různé arytmogenní mechanismy a mohou se lišit $\mathrm{v}$ časném a pozdějším období po OTS.

Denervace srdce po transplantaci může podmiňovat zvýšenou senzitivitu myokardu na cirkulující katecholaminy, což může přispívat $\mathrm{k}$ arytmogenicitě. Akutní rejekce štěpu $\mathrm{v}$ důsledku tvorby protilátek (humorální typ) či infiltrací tkáně štěpu aktivovanými lymfocyty (buněčný typ), př́ípadně kombinace obou typů rejekce může vést $\mathrm{k}$ měnlivému arytmogennímu substrátu, obdobně jako u myokarditid. Tento stav může vést $\mathrm{k}$ různým arytmiím včetně komorové tachykardie a fibrilace komor. Prvá epizoda rejekce se vyskytne obvykle $v$ prvních šesti měsících po OTS a postihuje až $60 \%$ pacientů. Většina nálezů buněčné rejekce není provázena typickými klinickými projevy. ${ }^{120}$ Diagnostika rejekce štěpu se opírá o echokardiografii či jiné zobrazovací metody, změnu EKG, biochemické ukazatele a především o endomyokardiální biopsii. Hlavní léčbou je intenzivní imunosuprese - při kontinuální monitoraci pacienta. ${ }^{120}$ Léčba komorové tachykardie zde nemá specifické postupy, odlišné od dilatační KMP. Závažné jsou rejekce s poruchou funkce štěpu, což bývá provázeno závažnými arytmiemi včetně komorových arytmií. Jednoroční mortalita po epizodě takového typu rejekce může dosahovat až $50 \%$. ${ }^{121}$ Těmto pacientům i po zvládnutí akutní rejekce musí být věnována zvýšená diagnostická a terapeutická péče. Špatnou prognózu mají zejména pacienti, u kterých porucha funkce štěpu není provázena známkami buněčné rejekce vyššího stupně. Je tedy zřejmé, že větší riziko pro štěp představuje rejekce humorální než buněčná. ${ }^{120}$ Nadějné jsou výsledky aplikací nových postupů u antirejekční léčby, které dle dosavadních výsledků snižují riziko výskytu akutních rejekcí. ${ }^{122}$

Chronická rejekce štěpu je charakterizována významným postižením věnčitých tepen. Pokud je u tohoto stavu výskyt závažných komorových arytmií, je možno indikovat léčbu ICD.

\subsubsection{Idiopatická fibrilace komor}

Tato zatím samostatně stojící diagnóza zahrnuje dokumentovanou komorovou fibrilaci bez prokazatelného strukturálního srdečního postižení či poruchy repolarizace nebo jiné abnormality na EKG, bez zjevné transitorní vyvolávající príčiny a bez známé genové mutace s arytmogenním potenciálem. ${ }^{123-125} \mathrm{U}$ jedinců s touto diagnózou není prokazatelná vazba vzniku arytmie na zátěž a není pozitivní rodinná anamnéza výskytu náhlé srdeční smrti. Vzhledem k tomu, že tuto diagnózu nelze stanovit předem a první manifestací bývá fibrilace komor, léčba ICD je zde indikována jen v rámci sekundární prevence náhlé srdeční smrti. ${ }^{3,126}$ Některé formy idiopatické fibrilace komor mohou být spouštěny fokální aktivitou, jejíž lokalizace může mít vazbu na periferní části převodního fascikulárního systému. Tyto formy mohou být ovlivněny katetrizační ablací. Tento léčebný postup je však brán jako doplňující k zajištění pacienta ICD. ${ }^{4}$

\section{Léčba komorových arytmií}

Indikace a výběr léčby u komorových arytmií zohledňuje symptomy a prognostickou závažnost dané arytmie, která je determinována vlastní charakteristikou dané poruchy rytmu a základním srdečním postižením, funkcí levé komory, nálezem na věnčitých tepnách a celkovým stavem organismu. Příznivým prognostickým ukazatelem je poměrně dobrá kontraktilní funkce nezvětšené levé komory (s ejekční frakcí levé komory $\geq 40 \%$ ) a nepřítomnost klinicky významnějšího strukturálního srdečního postižení. V medicínské praxi jsou leckdy neostré hranice mezi benigními a potenciálně maligními komorovými arytmiemi a mezi potenciálně maligními a maligními komorovými arytmiemi a komplexnost tohoto problému se promítá i do dalšího textu.

\subsection{Benigní a potenciálně méně závažné komorové arytmie}

V zásadě platí, že asymptomatická či málo symptomatická komorová extrasystolie nepredstavuje indikaci k léčbè. U nemocných bez strukturálního srdečního onemocnění je pouze důvodem k prospektivnímu sledování funkce levé komory.

Také u pacientů se symptomatickými formami komorové extrasystolie bez prokazatelného závažnějšího srdečního postižení se vyhýbáme podávání antiarytmik. Snažíme se ovlivnit danou situaci psychoterapií nebo léčbou anxiolytikem. $\mathrm{V}$ některých př́padech lze uspět podáním menší dávky beta-blokátoru. Léčbu antiarytmikem indikujeme až $\mathrm{v}$ př́ípadě, že symptomy jsou velmi výrazné a kdy se výše zmíněnými způsoby nepodařilo stav zklidnit. V této situaci bývá preferována menší dávka propafenonu či jiného antiarytmika s nižším proarytmickým potenciálem a s nižším výskytem závažnějších nežádoucích účinků. ${ }^{3}$ Alternativně může být indikována katetrizační ablace arytmogenního ložiska ${ }^{4}$ - viz též část 7.3. Katetrizační ablace je dominantní léčbou u idiopatických komorových tachykardií z výtokového traktu pravé či levé komory. Tyto tachykardie jsou obvykle fokálního původu nebo rázu reentry malého rozměru a mohou se vyskytovat v nesetrvalé i setrvalé formě a bývá i různě častý výskyt extrasystolie stejné morfologie. Tyto arytmie vycházejí častěji z výtokové části pravé komory a na EKG pak mají tvar blokády levého Tawarova raménka. Některé idiopatické komorové tachykardie z levé komory mohou vycházet $\mathrm{z}$ tkáně převodního systému a reagují na blokátory kalciových kanálů (tzv. verapamil-senzitivní komorová tachykardie). Vzhledem $\mathrm{k}$ tomu, že z prognostického hlediska jsou idiopatické komorové tachykardie považovány za benigní, je jejich léčba indikována především v případě zřetelnějších symptomů nebo $\mathrm{k}$ prevenci 
komorové dysfunkce při častějších a delších paroxysmech této ektopické aktivity.

Při častějších komorových extrasystolách u pacientů s koronární nemocí podáváme beta-blokátory - nikoli s cílem potlačit extrasystolii, ale ke snížení rizika IM a náhlé srdeční smrti. Tento postup se opírá o výsledky řady preventivních studií $\mathrm{s}$ beta-blokátory u pacientů po IM , které docílily snížení výskytu náhlé smrti o 25-45 \% oproti placebové skupině. ${ }^{3,127-129}$ Profylaktické podávání beta-blokátoru u ICHS má komplexnější účinek v neurohumorální regulaci. ${ }^{130}$ Výrazné snížení mortality náhlou smrtí i celkové mortality při léčbě beta-blokátory demonstrovaly i velké, randomizované studie u pacientů s městnavou srdeční insuficiencí u ischemické i neischemické kardiomyopatie. ${ }^{131,132}$ Na rozdíl od beta-blokátorů antiarytmika indikovaná k potlačení komorových extrasystol u pacientů s organickým srdečním postižením vedla ke zhoršení prognózy - viz data ze studie CAST. ${ }^{133}$ Výjimkou je amiodaron, jehož účinek na celkovou mortalitu je sice spíše neutrální, ale sníží výskyt arytmické smrti. ${ }^{134}$ Je možno ho indikovat k potlačení symptomatických forem komorových extrasystol u těchto nemocných. ${ }^{3}$

\subsection{Maligní komorové arytmie}

Tyto komorové arytmie jsou nejčastějším podkladem oběhové zástavy. Kromě dvou nejzávažnějších forem komorových arytmií - fibrilace a flutteru komor - řadíme do této skupiny s-KT, zejména hemodynamicky netolerované s-MKT, s-PKT a TdP.

\subsubsection{Akutní léčba}

Při výskytu hemodynamicky velice závažné komorové arytmie provázené těžkou hypotenzí (systolický TK $<90$ mm Hg, někdy označované jako „bezpulsové “ KA), manifestním srdečním selháním, projevy koronární nebo cerebrovaskulární insuficience či dokonce známkami oběhové zástavy je třeba provést neodkladně elektrickou transthorakální kardioverzi či defibrilaci a dle potřeby zahájit komplexní kardiopulmonální resuscitaci. Tato nanejvýš emergentní léčba je indikována bez ohledu na základní srdeční postižení a jeho pokročilost. Pravděpodobnost úspěšnosti defibrilace je nepřímo úměrná délce intervalu od počátku komorové fibrilace k prvnímu výboji. Podle novějších uznávaných doporučení má být dodržován při elektrické defibrilaci tento postup:3,135,136

> první defibrilační výboj má energii $200 \mathrm{~J}$,

> je-li neúspěšný, opakovat až dvakrát výboj o maximální energii (360 J),

> pokud první tři výboje byly neúspěšné, pokračovat v kardiopulmonální resuscitaci a současně zajistit následující opatření v rámci komplexní resuscitace: zavést žilní linku, provést endotracheální intubaci, podat adrenalin nitrožilně (i.v.), opakovat elektrickou defibrilaci,

, pokud defibrilace opět nebyla úspěšná, aplikovat amiodaron 150 mg i.v., popř. lidocain (v našich podmínkách trimecain, $100 \mathrm{mg}$ i.v.) či magnesium sulfuricum (jako bolus odpovídající 8-17 mmol) i.v., event. beta-blokátor
(2-3 mg i.v.) a opakovat elektrickou kardioverzi - a při trvající hyposystolii pokračovat $\mathrm{v}$ kardiopulmonální resuscitaci.

Při výskytu polymorfní komorové tachykardie typu TdP při sekundárně prodlouženém intervalu QT je vhodné aplikovat magnesium nitrožilně, korigovat sérovou koncentraci kalia a zkrátit délku základního srdečního cyklu (dočasnou kardiostimulací nebo infuzí isoproterenolu).

Dle dosavadních výsledků dostačuje při použití bifázického defibrilačního impulsu k docílení úspěšné defibrilace nižší energie než při použití monofázického impulsu. ${ }^{3}$ Pokud má pacient implantovaný kardiostimulátor nebo kardioverter-defibrilátor, je vhodné umístit defibrilační elektrody při transthorakální defibrilaci do alternativní polohy (například anteroposteriorní - tj. nad dolní část sterna a na protilehlé místo na zádech mezi lopatkami) a dodržet minimální vzdálenost zevní defibrilační elektrody alespoň 20-25 cm od implantátu.

Přežívání pacientů s oběhovou zástavou na podkladě maligní komorové arytmie závisí na co nejčasnější elektrické defibrilaci, přičemž za kritický interval je považováno rozmezí do 4-5 minut od začátku uvedené arytmie. ${ }^{137}$ Perspektivně může hrát roli zajištění snadné dostupnosti účinné srdeční defibrilace s využitím automatických externích kardioverterů-defibrilátorů. ${ }^{3,137,138}$ Přes docílení časnější laické defibrilace pomocí automatických externích kardioverterů-defibrilátorů jsou výsledky randomizovaných studií s těmito přístroji zaměřené na přežívání pacientů po kardiopulmonální resuscitaci zatím nepřesvědčivé. ${ }^{138}$

Bezprostředně po neodkladné elektrické kardioverzi či defibrilaci závažné komorové arytmie je třeba rychle posoudit možnost vlivu prrípadné reverzibilní poruchy na vzniku a udržení tachyarytmie, a pokud taková okolnost existuje, zaměřit léčebné úsilí na její korekci (léčba akutního koronárního syndromu a městnavé srdeční insuficience, léčba hypoxemie či rozvratu vnitřního prostředí, minerálové dysbalance, lékové nebo jiné intoxikace aj.). ${ }^{3}$

Jednou z nejčastějších reverzibilních přičin maligních komorových arytmií je akutní ischemie myokardu, zejména při akutním IM. Vhodné léčebné postupy během přednemocniční i nemocniční fáze léčby akutního IM jsou předmětem př́slušných doporučení, jejichž cílem je dosažení co nejčasnější reperfuze myokardu a snížení rizika časných i pozdějších komplikací včetně závažných komorových arytmií. Spíše negativní stanovisko je k preventivnímu použití lidocainu u akutního IM ke snížení rizika fibrilace komor v akutní fázi koronární př́ihody. Důvodem je publikace o neúčinnosti tohoto postupu ve studiích GUSTO I a GUSTO II-b. ${ }^{139}$ Přes tuto skepsi se nedávno objevilo pozitivní stanovisko $\mathrm{k}$ podání tohoto antiarytmika v rámci jednorázové nitrožilní aplikace (bolus $100 \mathrm{mg}$ ) a následné infuze v celkové dávce $1 \mathrm{~g}$ po dobu 24 hodin. Opírá se o dlouholetou observační studii u více než 4000 pacientů, u nichž po podání lidocainu byl výskyt tzv. primární fibrilace komor jen v 0,5 \%, zatímco bez této medikace to bylo v $10 \%$ př́padů ( $<<0,0001)$. Výskyt významnějších bradyarytmií po podání lidocainu byl kolem 
$0,5 \% .{ }^{140}$ Je však problematické vztahovat tato data na dnešní postupy při léčbě akutního koronárního syndromu, které jsou výrazně odlišné.

\subsubsection{Dlouhodobá léčba}

$\mathrm{V}$ př́ípadě, že není prokázána reverzibilní příčina, jsou pacienti po proběhlé epizodě maligní komorové arytmie ohroženi recidivami komorových arytmií. V terapii těchto stavů převažují nefarmakologické léčebné metody. Dominantní postavení v léčbě závažných komorových tachykardií zaujímá ICD. Indikaci léčby ICD v těchto prrípadech řadíme do sekundární prevence náhlé srdeční smrti. Opodstatnění této léčby se opírá - jak je již uvedeno výše - především o výsledky tři prospektivních randomizovaných studií AVID, CIDS a CASH. ${ }^{141-143}$ Jejich závěry jsou konzistentní a při dvouletém a delším sledování ukazují relativní snížení mortality o 20-37 \% ve prospěch ICD oproti amiodaronu či jinému antiarytmiku. Vliv ICD na snížení výskytu arytmické smrti byl ještě výraznější - až 57 \%. Při metaanalýze uvedených tří sekundárně preventivních studií bylo konstatováno relativní snížení mortality $\mathrm{z}$ důvodu náhlé smrti o $57 \%$. ${ }^{144}$ $\mathrm{V}$ uvedených studiích převažovali pacienti s koronární nemocí, menši část byla zastoupena pacienty s dilatační kardiomyopatií. $\mathrm{V}$ rámci obecně uznávaných indikací ICD jsou v indikační tř́dě I (s úrovní dủkazů ve skupině A) zařazeny stavy s dokumentovanou s-KT/fibrilací komor jak při organickém srdečním postižení, tak u arytmických syndromů bez prokazatelného strukturálního onemocnèní myokardu. ${ }^{1-3}$

Další léčebnou možností, která může být dokonce kurativním výkonem, je cílená katetrizační nebo chirurgická ablace arytmogenního substrátu. Typickým arytmogenním substrátem u pacientů po infarktu myokardu je oblast jizvy a jejího okolí. ${ }^{145,146}$ Pokud jde o stabilní reentry okruh, je možno jej úspěšně ovlivnit cílenou katetrizační ablacíi, 103,145,147 - viz též část 7.3.2. $\mathrm{V}$ případě hemodynamicky netolerované s-KT, kde situace nedovoluje aktivační a stimulační mapování během tachykardie, je možno provést endokardiální (resp. epikardiální) mapování arytmogenního substrátu po přerušení komorové tachykardie - tedy při sinusovém rytmu. Cílem v tomto případě je lokalizovat a katetrizační ablací modifikovat oblasti frakcionovaných, nízkoamplitudových signálů a pozdních komorových potenciálů, které mohou hrát roli při vzniku reentry mechanismu. ${ }^{4,103}$ Nové techniky s využitím tzv. elektroanatomického mapování a účinnější katetrizační ablace (např́iklad s použitím katetrů s chlazeným hrotem $\mathrm{k}$ docílení hlubších lézí) zvyšují úspěšnost ablačních metod. ${ }^{148} \mathrm{U}$ některých forem s-KT, které mají kritickou část reentry okruhu lokalizovanou subepikardiálně jak u ischemického, tak u neischemického strukturálního srdečního postižení - je možno použít epikardikální přístup $\mathrm{k}$ provedení katetrizační ablace. ${ }^{149,150}$ Problémem u ablační léčby je, že neexistují dostatečná data o tom, zda je možno ponechat pacienty s významným strukturálním postižením srdce po úspěšné katetrizační ablaci bez zajištění ICD.

$\mathrm{V}$ tomto směru probíhají nyní prospektivní studie a jasnější odpověd' budeme mít v průběhu dalších let. U pa- cientů, kteří mají komorovou tachykardii a jsou indikováni ke kardiochirurgickému výkonu (například k revaskularizaci myokardu), je možno provést též chirurgickou ablaci arytmogenního ložiska (například resekci či kryodestrukci) dle peroperačního endokardiálního a epikardiálního mapování srdečních signálů. ${ }^{151-153} \mathrm{Z}$ dosavadních zkušeností u nevelkých souborů nemocných je zřejmé, že kombinace revaskularizace a resekce (nebo modifikace) arytmogenního substrátu znamená dobrou prognózu i bez zajištění ICD. ${ }^{152,153}$ Tento postup je součástí tzv. hybridní terapie, přičemž modifikace arytmogenního substrátu může snížit frekvenci epizod komorové tachykardie nebo usnadní jejich potlačení elektroterapií ICD.

Problematika katetrizačních ablací (K-Ab) je podrobněji zmíněna $v$ dalším textu. Současné indikace $\mathrm{k}$ léčbě K-Ab shrnuje tabulka 8 . Zatím platí zásada, že při vyvolatelnosti dalších (tzv. neklinických) forem komorové tachykardie po ablační léčbě trvá indikace $\mathrm{k}$ léčbě ICD.

$\mathrm{V}$ ojedinělých př́padech je u jinak neovlivnitelných hemodynamicky netolerovaných komorových arytmií indikována ortotopická transplantace srdce či přechodně mechanická srdeční podpora.

\subsubsection{Léčba „arytmické bouře" u pacienta s ICD}

Mezi nejzávažnější problémy u pacientů s ICD patří stav velmi častých epizod komorových arytmií, někdy až rázu nepřetržité (incesantní) s-KT, což vede k opakovaným výbojům ICD během krátkého časového intervalu. Aryt-

\section{Tabulka 8 Indikace katetrizační ablace u komorových arytmií}

Nemocní se strukturálním onemocněním srdce (po IM, DKMP, ARVC/D) Ablace je doporučena:

1. symptomatické setrvalé monomorfní KT (včetně KT terminované ICD), které recidivují pres terapii $A A$, nebo terapie $A A$ není preferována či tolerována

2. setrvalé monomorfní KT nebo arytmická bouře, která není způsobena přechodnou, odstranitelnou príčinou

3. frekventní KES, ns-KT a KT vedoucí k rozvoji komorové dysfunkce

4. bundle branch reentry a interfascikulární KT

5. recidivující setrvalá polymorfní $\mathrm{KT}$ a $\mathrm{KF}$, refrakterní na terapii $\mathrm{AA}$

Nemocní bez strukturálního onemocnění srdce

Ablace je doporučena:

1. frekventní KES, NSKT, monomorfní KT provázená výraznou symptomatologií nebo vedoucí k rozvoji komorové dysfunkce

2. frekventní KES, NSKT, monomorfní KT, kde terapie AA selhala, ev. není preferována nebo tolerována

3. recidivující setrvalá polymorfní KT nebo KF (arytmická bouře), refrakterní na terapii AA

Ablace není doporučena

1. prítomnost mobilního trombu $v$ komoře (epikardiální ablace může být zvážena)

2. asymptomatické KES a/nebo ns-KT, které nezpůsobují komorovou dysfunkci

3. KT způsobená přechodnou, odstranitelnou příčinou (ischemie, iontová dysbalance, intoxikace, farmaky navozená TDP)

AA - antagonisté aldosteronu, IM - infarkt myokardu; DKMP - dilatační kardiomyopatie; ARVC/D - arytmogenní kardiomyopatie/arytmogenní dysplazie pravé komory; KT - komorová tachykardie; ICD - implantabilní kardioverter-defibrilátor; AA - antiarytmická; KES - komorová extrasystolie; ns-KT - nesetrvalá komorová tachykardie; KF - fibrilace komor; TDP - torsade de pointes 
mická (či elektrická) bouře je definována jako tři nebo více oddělených epizod komorové tachykardie/fibrilace komor během 24 hodinového intervalu, vedoucí k opakovaným intervencím ICD nebo označeným v rámci monitorace ICD jako s-KT. Tato problematika je podrobněji řešena $\mathrm{v}$ rámci př́slušných doporučení. ${ }^{154}$

Zde jen připomeneme, že je nezbytné co nejrychleji vyloučit a prŕpadně korigovat dysbalanci sérových minerálů, akutní ischemii myokardu, projevy srdečního selhávání či jinou sekundární př́činu komorových arytmií. Pacient s tímto velice závažným akutním stavem má být celkově zklidněn a co nejrychleji přeložen (s důsledným dodržením všech podmínek bezpečného transportu s možností komplexní resuscitace) do implantačního centra, které kromě reprogramace ICD je schopno zajistit veškerou potřebnou terapii včetně př́padné urgentní revaskularizace myokardu a neodkladné cílené katetrizační ablace či modifikace arytmogenního substrátu nebo použití mechanické srdeční podpory. ${ }^{154,155}$

\subsection{Potenciálně maligní komorové arytmie}

Léčba potenciálně maligních komorových tachyarytmií zatím zůstává dosti problematickou. Záchyt $n s-K T$ u pacienta se strukturálním srdečním postižením vyžaduje komplexnější posouzení, které má určitá specifika u jednotlivých diagnóz. ${ }^{91,92}$

Ns-KT u pacientů s koronární nemocí, po IM, v trombolytické éře má nejistou prediktivní hodnotu při posuzování rizika náhlé srdeční smrti, pokud je hodnocena izolovaně. Ve spojení s dalšími ukazateli, jako je snížená kontraktilní funkce levé komory či indukovatelnost s-KT při programované komorové stimulaci, však umožňuje identifikovat pacienty s podstatně vyšším rizikem náhlé srdeční smrti. ${ }^{3,156}$ Následná volba léčby je shrnuta v tabulce 7 .

Význam elektrofyziologického testování pro stratifikaci rizika ohrožení závažnými komorovými tachyarytmiemi byl prokázán především u pacientů po infarktu myokardu, s ns-KT a se sníženou systolickou funkcí levé komory srdeční. ${ }^{43,157-160}$

\subsubsection{Indikace a výsledky léčby ICD}

Z výsledků výše zmíněných studií MADIT a MUSTT týkajících se tzv. primárně preventivní indikace ICD vyplynulo, že dopad léčby ICD na snížení celkové mortality u rizikových pacientů s ICHS byl ještě výraznější než ve studiích sekundárně preventivních. Relativní snížení celkové mortality bylo v těchto studiích kolem $55 \%{ }^{43,157}$ Přestože existuje řada kritických poznámek k oběma uvedeným studiím, jejich přesvědčivé a konzistentní výsledky přispěly $\mathrm{k}$ tomu, že do obecně uznávaných doporučení pro léčbu ICD jsou $\mathrm{v}$ indikační třídě I již zahrnuty primárně preventivní indikace u definované skupiny pacientů. ${ }^{1-3}$

Vzhledem ke zjištění, že ve studii MADIT měli největší prospěch $\mathrm{z}$ léčby ICD pacienti s těžkou dysfunkcí levé komory, pokračovala snaha o jednoduchou stratifikaci pacientů $s$ ischemickou chorobou srdeční a snadnou identifikaci kandidátů na profylaktickou implantaci ICD. ${ }^{161}$ Byla realizována studie MADIT II, cílená na pacienty s ejekční frakcí levé komory $\leq 30 \%{ }^{162}$ Studie byla ukončena předčasně, nebot' v intervalu kratším než dva roky bylo zjištěno výrazné relativní snížení celkové mortality (o $31 \%$ ) ve skupině pacientů s ICD. V podskupině pacientů s rozšířeným komplexem QRS > 120 ms bylo relativní snížení celkové mortality dokonce o $63 \%$ oproti skupině, léčené konvenčně farmakologicky. ${ }^{162}$ Dle současných akceptovaných doporučení je tato indikace $\mathrm{k}$ implantaci ICD rovněž zařazena do indikační tř́idy $\mathrm{I}^{1-3}$ (viz tabulka $3 \mathrm{v}$ části 6.1).

Účinnost léčby ICD je ovlivněna též časovým odstupem od proběhlého infarktu myokardu.

Subanalýza studie MADIT II ukázala, že přínos z léčby ICD měli především pacienti, kteři měli při zařazení do studie delší odstup (> 1,5 roku) od IM, relativní riziko jednoroční mortality při zajištění ICD bylo 0,55 oproti 0,97 u pacientů, kde byla implantace ICD do 18 měsíců po IM. ${ }^{163}$

Tento nález koresponduje s výsledky dvou randomizovaných studií (DINAMIT a IRIS), které zařadily pacienty do 40 dnů od koronární prŕhody. Tyto studie neprokázaly přínos ICD na snížení celkové mortality při zhruba dvouletém až tř́letém sledování. ${ }^{164,165}$ Jedním $\mathrm{z}$ vysvětlení je, že relativně vysoká mortalita $\mathrm{v}$ prvních měsících po IM je podmíněna převážně progredující koronární nemocí a negativní remodelací myokardu. Související komorové arytmie jsou pouze sekundární a případná intervence pomocí ICD neovlivní celkovou mortalitní prognózu. Naopak v delším časovém odstupu od IM u hemodynamicky a koronárně stabilních pacientů s vyzrálým arytmogenním substrátem vznikají „primární" komorové arytmie, jejichž intervence ICD může zásadně ovlivnit prognózu pacientů. ${ }^{163}$ Doplňující analýza mortality ve studii DINAMIT skutečně ukázala, že v prvním roce po IM byl relativně vysoký podíl nearytmické kardiální smrti - nejčastěji v důsledku srdečního selhání či rekurentní koronární příhody. ${ }^{166}$ Také další nedávno publikovaná analýza náhlých úmrtí ve studii VALIANT s valsartanem u pacientů po IM ukázala významný podíl rekurentních IM a ruptur myokardu v časném období (zejména v prvním měsíci) po IM. ${ }^{167}$ Roli časového faktoru odstupu od IM postihují rovněž recentně zveřejněné výsledky osmiletého sledování pacientů ze studie MADIT II, svědčící pro prríznivý efekt ICD, který se s pokračujícím časem spíše zvětšuje (34\% relativní snížení mortality ve srovnání s výchozími $31 \%$ při počátečním hodnocení této studie). ${ }^{168}$

Můžeme shrnout, že současná riziková stratifikace u pacientů po IM není ještě dostatečně jasná - především $\mathrm{v}$ časném období prvních šesti týdnů po IM. V rámci praktického postupu při posuzování rizika náhlé srdeční smrti před dimisí po léčbě akutního IM lze zatím doporučit stratifikaci shrnutou v tabulce 2. Je třeba mít na žreteli, že při indukovatelnosti s-KT může hrát roli i reziduální ischemie myokardu. ${ }^{169}$ Pokračuje výzkum k ověření př́nosu neinvazivních metod pro přesnější stratifikaci rizika náhlé srdeční smrti po IM, ${ }^{3,41,170}$ aby případné další rozšírení primárně preventivní indikace léčby ICD mělo odpovídající medicínský přínos a bylo též ekonomicky efektivní.

Problematika indikací léčby ICD u neischemických kardiomyopatií i u primárních arytmických syndromů je 
opakovaně zmíněna $\mathrm{v}$ textu výše. 3,39,40,47,49-52,55,80,81,126 Také zde přibývají nové poznatky a lze očekávat $\mathrm{v}$ příštích letech zpřesnění v rizikové stratifikaci. ${ }^{171}$

Léčba ICD je spojena s určitou specifickou morbiditou a s výskytem komplikací. Jejich výskyt, diagnostika a řešení jsou shrnuty $\mathrm{v}$ materiálech cílených na tuto problematiku. ${ }^{1,2,172,173}$

Implantace ICD jsou v ČR prováděny v akreditovaných centrech a podmínky pro provádění této léčby a pro zajištění kontrol pacientů s ICD jsou jasně stanoveny. ${ }^{2}$

\subsubsection{Indikace a výsledky katetrizační ablace}

Katetrizační ablace (K-Ab) je v současnosti považována za významnou léčebnou metodu prevence rekurence komorových arytmií. Katetrizační ablace je často preferovanou terapií frekventní symptomatické komorové extrasystolie a komorové tachykardie u pacientů bez strukturálního onemocnění srdce. $U$ pacientů s organickým srdečním postižením je K-Ab v narůstající míře využívána v kombinaci s ICD a/nebo s antiarytmickou farmakoterapií. Následující text se především opírá o dva recentně publikované dokumenty vzniklé na základě mezinárodního konsensu. ${ }^{4,103}$ Uvedená doporučení vycházejí z převážné části z nerandomizovaných a nekontrolovaných studií, zkušeností a výsledků publikovaných z jednotlivých center.

Vzhledem k tomu, že využití K-Ab v léčbě komorových arytmií je častější až v posledních několika letech, uvedeme zde alespoň nejzákladnější informace o této léčebné technologii.

Předpokládaný mechanismus komorové tachykardie zásadním způsobem určuje výběr mapovací strategie a stanovení cílového momentu ablačního výkonu. Je potvrzován $\mathrm{v}$ průběhu elektrofyziologického vyšetření srdce. U idiopatické komorové tachykardie fokální původ nebo kritická část reentry okruhu obvykle představuje velmi malou oblast, která je cílem mapování a lze ji ovlivnit diskrétní ablační lézí. U komorových tachykardií, které vznikají nejčastěji v oblasti fibroticky postiženého myokardu, je cílovým momentem ovlivnění tzv. kritického isthmu, který je součástí reentry okruhu komorové tachykardie. Pokud je tento kritický isthmus úzký, pak bývá snadno ovlivnitelný K-Ab. Naopak velmi široký isthmus vyžaduje aplikace radiofrekvenční energie $\mathrm{v}$ poměrně rozsáhlé oblasti. U pacientů s nemapovatelnými či mnohočetnými komorovými tachykardiemi jsou nutné rozsáhlé aplikace radiofrekvenční energie v oblastech, které jsou kritické pro reentry okruhy. ${ }^{4,103,145,146}$ U komorové tachykardie, které vznikají v důsledku prodělaného infarktu myokardu, lze většinu reentry okruhů ovlivnit $\mathrm{K}-\mathrm{Ab} \mathrm{z}$ endokardiálního př́stupu. Nicméně kritické části reentry okruhu mohou být lokalizovány i intramurálně nebo dokonce subepikardiálně, tyto případy jsou častější především u některých kardiomyopatií. ${ }^{150}$ Specifickou skupinu komorových tachykardií pak představují arytmie, které vycházejí z převodního srdečního systému nebo z Purkyňových vláken.

Nedílnou součástí většiny ablačních výkonů je pochopení anatomie, které je nezbytné pro mapování a ablaci arytmie.
Z tohoto důvodu se v současné době stále více využívají zobrazovací metody (MR, CT, PET-CT apod.), které jsou prováděny před plánovaným výkonem. Především kontrastní magnetická rezonance srdce představuje významnou a př́nosnou zobrazovací metodu, která dokáže zhodnotit lokalizaci a kvantifikaci rozsahu myokardiální fibrózy a rozlišit některé typy ischemických a neischemických kardiomyopatií. Každý pacient, u kterého je K-Ab zvažována, musí být pečlivě a kompletně kardiovaskulárně vyšetřen. Nezbytné je ve většině př́padů koronarografické vyšetření a při průkazu významného postižení koronárních tepen provedení revaskularizace. Arytmie by měly být optimálně zachyceny na 12 svodovém EKG. Bezprostředně před ablací v levé komoře je doporučeno vyloučení přítomnosti trombu.

Podrobnější popis v současnosti využívaných technologií pro mapování komorových arytmií a jejich $\mathrm{K}-\mathrm{Ab}$ považujeme za přesahující rozsah tohoto textu. Mezi nejvíce využívané technologie patří elektroanatomické mapovací systémy, non-kontaktní mapovací systémy, intrakardiální ultrazvuk, robotická či magnetická navigace. Pro vlastní ablaci je nejčastěji používána radiofrekvenční energie, která je účinná a její aplikace je relativně jednoduchá. Chlazený ablační katetr umožňuje provedení rozsáhlejší ablační léze. $\mathrm{V}$ některých prrípadech je využívána $\mathrm{v}$ klinické praxi i kryoablace, která může být s výhodou použita především v blízkosti koronárních tepen a u dětí.

Cílové momenty $\mathrm{K}-\mathrm{Ab}$ mohou být různé. U setrvalé monomorfní komorové tachykardie, která je vyvolatelná při programované komorové stimulaci, je cílem ablační léčby nevyvolatelnost komorové tachykardie. Jistým omezením může být obtížná vyvolatelnost a nižší reproducibilita spontánních (klinických) komorových tachykardií při programované komorové stimulaci. Obecně lze konstatovat, že obvykle hodnotíme jeden ze tří cílových momentů K-Ab: 1) nevyvolatelnost klinické komorové tachykardie; 2) modifikaci vyvolatelné komorové tachykardie; 3) nevyvolatelnost jakékoli komorové tachykardie (s výjimkou flutter komor nebo fibrilace komor).

V některých případech lze zvážit chirurgickou ablaci komorových tachykardií, která je však v době implantabilních ICD méně častá. Lze ji považovat za alternativní metodu zejména u pacientů po prodělaném infarktu myokardu s rozvojem aneurysmatu levé komory, kteří jsou indikováni $\mathrm{k}$ revaskularizační operaci, popř́padě k resekci aneurysmatu. Tato problematika je již stručně zmíněna v textu výše. Velmi vzácně používanou metodou pro terapii komorové tachykardie je aplikace etanolu do větví koronárních tepen vyživujících oblast myokardu, ve které komorové tachykardie vzniká. Metoda je indikována, pokud jde o komorovou tachykardii nereagující na antiarytmika a ani na předchozí katetrizační endokardiální nebo epikardiální ablační výkony. ${ }^{4,103}$

\section{Indikace katetrizační ablace}

Při rozhodování o provedení K-Ab je nezbytné u každého pacienta vycházet $\mathrm{z}$ posouzení př́nosu a rizika s ohledem na jeho klinický stav a charakteristiku arytmie. U pacientů se strukturálním srdečním onemocněním a s implantova- 
ným ICD je výskyt setrvalé komorové tachykardie známkou zvýšeného rizika časnější mortality a snížené kvality života. ${ }^{174}$ Antiarytmika či jiná farmaka mohou vést $\mathrm{k}$ redukci frekvence antitachykardické terapie ICD, na druhé straně však může být tato léčba bez efektu nebo doprovázena výskytem nežádoucích účinků. Současné technologické možnosti, znalost arytmogenního substrátu a pochopení mechanismů komorové tachykardie umožňují provádění $\mathrm{K}-\mathrm{Ab}$ u mnohočetných či nestabilních komorových tachykardií s akceptovatelnou bezpečností a účinností, a to i u pacientů s významným organickým srdečním postižením. Proto se nyní u pacientů s opakovanými epizodami komorových tachykardií, které vedou k adekvátní terapii $\mathrm{ICD}$, upřednostňuje $\mathrm{K}-\mathrm{Ab}$ před farmakoterapií. Je třeba zdůraznit, že se v těchto případech doporučuje provedení ablace co nejdříve. Jak je již uvedeno výše, indikace K-Ab jsou uvedeny $\mathrm{v}$ tabulce 8 .

\section{Komplikace katetrizační ablace}

U idiopatických komorových tachykardií jsou závažné komplikace ablační léčby vzácné (<1\%). U komorových tachykardií vznikajících v terénu strukturálního srdečního postižení je popisována incidence významných komplikací K-Ab ve $4-8 \%$ a až 3\% mortalita v závislosti na proceduře. ${ }^{4,103}$ Přičinou smrti je obvykle nepřetržitá komorová tachykardie, která odráží neúspěch $\mathrm{K}-\mathrm{Ab}$ a v některých těchto případech nelze vyloučit ani proarytmický efekt $\mathrm{K}-\mathrm{Ab}$. U pacientů po prodělaném infarktu myokardu ukazují publikované randomizované multicentrické studie výskyt komplikací K-Ab komorových tachykardií < $5 \%$. Výskyt vaskulárních komplikací je závislý na použitém přístupu (retrográdní či transseptální), komplikace (žilní trombóza, pseudoaneurysma, arteriovenózní píštěl, atd.) jsou uváděny u 0,2-6 \% výkonů. Tromboembolické komplikace (plicní embolizace, cévní mozková př́hoda, transitorní ischemická ataka, systémová embolizace) se pohybují mezi $1-3 \%$. K srdeční tamponádě dochází u 0,4-2,7 \% výkonů. Vzácně může dojít při K-Ab k poškození převodního srdečního systému (<1\%). Mezi další komplikace patří poškození chlopně, poškození koronárních tepen, ischemie myokardu, srdeční selhání. ${ }^{4,103,175}$ Při použití epikardiálního př́istupu je popisováno perikardiální krvácení a následná perikarditida až u $30 \%$ př́padů. ${ }^{176}$

\section{Úspěšnost katetrizační ablace}

Výsledky katetrizační ablační léčby závisí především na typu arytmie a na přítomnosti či neprrítomnosti strukturálního srdečního postižení. U idiopatických komorových extrasystol/komorových tachykardií je dosahována bezprostřední úspěšnost 80-97 \% s rekurencí arytmie < $5 \%$.,103 U nemocných po prodělaném infarktu myokardu je popisována bezprostřední úspěšnost K-Ab 70-95 \% (u jednoho typu komorové tachykardie), resp. 38-72 \% (u více typů komorové tachykardie), s rekurencí komorové tachykardie do $35 \%$.

U nemocných s dilatační kardiomyopatií je dlouhodobá úspěšnost ablace 50-80\% s výjimkou bundle branch reentry komorové tachykardie, kde je úspěšnost $\mathrm{K}-\mathrm{Ab}$ $100 \%$. Úspěšnost K-Ab v léčbě komorové tachykardie u nemocných s vrozenou srdeční vadou dosahuje až $90 \%$ (rekurence komorové tachykardie je < 20 \%). Bezprostřední úspěšnost $\mathrm{K}-\mathrm{Ab}$ pro komorové tachykardie u nemocných $\mathrm{s}$ arytmogenní kardiomyopatií se pohybuje $\mathrm{v}$ rozmezí 40-90\%, dlouhodobá úspěšnost mezi 20-90\%, rekurence komorové tachykardie v rozmezí 10-50 \%. ${ }^{4,103}$

Můžeme shrnout, že K-Ab v léčbě komorových arytmií mají větší úspěšnost díky technologickým pokrokům a rozšiřujícím se poznatkům o patofyziologickém podkladu komorové tachykardie. Volba této léčby u konkrétního pacienta musí být výsledkem rozhodnutí jak lékaře, tak pacienta, s přihlédnutím na další komorbidity, celkový klinický stav pacienta a předpokládané riziko daného výkonu.

\subsection{Komorové tachyarytmie u specifické populace}

U některých skupin pacientů má problematika komorových arytmií specifický ráz a může vyžadovat částečně odlišný př́stup při hodnocení klinického významu dané arytmie a při výběru a vedení léčby. Dále jsou uvedeny jen čtyři vybrané skupiny, u kterých se můžeme častěji setkat s řešením diagnostiky a léčby komorových arytmií.

\subsubsection{Gravidita}

Komorové arytmie v průběhu gravidity jsou léčeny v podstatě stejným způsobem jako $\mathrm{v}$ období mimo těhotenství a hlavním aspektem je zde co nejvíce konzervativní a šetrný postup léčby ${ }^{177}$ s tím, že pokud to situace umožní, je definitivní léčba odložena na období po skončení gravidity. Je třeba zdůraznit, že všechna obecně používaná antiarytmika procházejí placentární bariérou, amiodaron je však vhodnější, nebot' jeho přechod placentou je nižší (fetální koncentrace dosahuje jen $20 \%$ koncentrace v těle matky), ${ }^{178}$ má menší negativní vliv na srdeční kontraktilitu a nižší proarytmický potenciál oproti jiným antiarytmikům. Amiodaron však hojně přestupuje do mateřského mléka, a proto by při jeho používání mělo být zastaveno kojení. ${ }^{178}$ Dalším lékem, který lze $\mathrm{v}$ graviditě akceptovat $\mathrm{k}$ ovlivnění rizika komorových arytmií, jsou selektivní blokátory $\beta_{1}$-receptorů. ${ }^{179} \mathrm{Hemo-}$ dynamicky závažné či život ohrožující setrvalé komorové arytmie mají být ukončeny elektrickou kardioverzí. ${ }^{178,179}$ Stav po implantaci ICD nepředstavuje kontraindikaci budoucí gravidity, ${ }^{180}$ rozhodující je stav kardiovaskulární kompenzace, daný základním kardiálním onemocněním.

\subsubsection{Sportovci}

Je známo, že riziko náhlé srdeční smrti u výkonnostních a vrcholových sportovců je vyšší (s relativním rizikem 2,5) než u věkově srovnatelné populace, která není vystavena větší sportovní zátěži. ${ }^{181}$ Jako hlavní příčiny náhlé srdeční smrti u sportovců jsou uváděny hypertrofická KMP, arytmogenní KMP, koronární anomálie (především odstup levé věnčité tepny $\mathrm{z}$ pravého koronárního sinu), myokarditida, „komoce“ srdeční - po úderu na hrudník aj. 3,106,181,182 Byly též popsány častější komorové arytmie u vytrvalostních běžců, přičemž u nich byl častější výskyt morfologického postižení pravé komory. ${ }^{183}$ 
Zavedení jednoduchého screeningu (anamnestické údaje, základní fyzikální vyšetření, 12svodové EKG), případně doplněné echokardiografickým a zátěžovým EKG vyšetřením, může vést $\mathrm{k}$ podstatnému snížení rizika náhlé srdeční smrti u sportovců s asymptomatickým průběhem určitého kardiálního onemocnění či vrozené kardiální abnormality ${ }^{93,84,185}$ Již základní EKG křivka může zachytit abnormality s arytmogenním potenciálem (EKG obraz komorové preexcitace typu WPW, prodloužený interval QT, obraz předčasné repolarizace, známky hypertrofie levé komory aj.). U pacientů se zjevným kardiálním postižením (jako je HKMP) je doporučeno zanechání vrcholového sportu. Na podrobnější informace o posuzování schopnosti k provozování závodního a rekreačního sportování při různých kardiovaskulárních poruchách a při výskytu arytmií odkazujeme na př́slušnou literaturu. ${ }^{186}$

\subsubsection{Staří pacienti, polymorbidní pacienti}

Věková hranice stáři je arbitrární: začíná dosažením 65 let, věk nad 80 let je označován jako vysoké stáří a věk nad 90 let jako dlouhověkost. Dle dosavadních trendů a demografických odhadů vzroste podíl osob starších 65 let v ČR v roce 2020 přibližně na $19 \% .^{187}$

Fyziologické stárnutí srdce je spojeno s řadou morfologických a funkčních změn, které s sebou nesou i zvýšené riziko výskytu arytmií, včetně komorové arytmie. Při 24hodinovém ambulantním monitorování EKG lze zachytit častější komorové extrasystoly či komplexní formy komorových extrasystol až u 20-30 \% osob nad 65 let věku, přestože nemají známky zjevného srdečního onemocnění. ${ }^{188}$ Při akutních koronárních syndromech mají starší pacienti vyšší výskyt náhlé oběhové zástavy, přičemž relativní riziko náhlé srdeční smrti je 1,6 u pacientů starších 75 let. ${ }^{189}$ Co se týká terapie komorových arytmií, v zásadě platí, že se u starších pacientů neodlišuje podstatněji od mladší populace. ${ }^{3}$ Pokud používáme farmakoterapii - nejspíše beta-blokátory či amiodaron - je vhodné podávat nižší dávky a dávat pozor na lékové interakce vzhledem k častějším komorbiditám u starších pacientů a obvyklé medicínské praxi podávání více různých léčiv u seniorů. ${ }^{187}$

V klinických studiích s indikací léčby ICD v rámci sekundární i primární prevence náhlé srdeční smrti byl u starších pacientů (> 65 let věku) demonstrován obdobný prrínos z léčby ICD jako u mladších osob. ${ }^{3,141,162,190,191}$ Zvažování vhodnosti léčby ICD u starších pacientů má brát na zřetel biologický věk pacienta, jeho celkový stav a životní aktivity a očekávanou životní prognózu s ohledem na případné komorbidity. Věk sám o sobě nepředstavuje limitaci pro indikaci léčby ICD. ${ }^{1-3}$

Polymorbidní pacienti: Pacienti, kteři trpí kromě kardiovaskulárního postižení dalšími závažnějšími zdravotními poruchami, mohou mít kromě řady prríznaků též zachycené symptomatické i asymptomatické komorové arytmie. Výběr a vedení léčby jsou u těchto stavů značně problematické vzhledem $\mathrm{k}$ přítomnosti většího počtu měnících se faktorů, které mohou ovlivňovat manifestaci arytmie i účinek léčby (iontová dysbalance, hypoxemie, hyperkapnie, acidóza, hypoglykemie či hyperglykemie aj.). Posuzování těchto stavů vyžaduje dostatečné klinické zkušenosti a nemůže se řídit zjednodušenými schématy.

Mezi významné komorbidity, které dramaticky ovlivňují prognózu pacientů a tak ovlivňují př́padnou léčbu komorových arytmií, patří kromě řady onkologických onemocnění též stavy s pokročilým chronickým renálním selháním. ${ }^{3} \mathrm{U}$ těchto stavů se při léčbě musíme zajímat o aktuální sérové koncentrace minerálů (kalia, magnesia, kalcia). Při výskytu hemodynamicky závažných komorových arytmií u pacientů, kteř́ jsou pravidelně dialyzováni, můžeme zvažovat i implantaci ICD, ale aktuální klinický stav by měl být stabilizovaný a měl by dávat předpoklad na přežívání delší než jeden rok. Naopak u pacientů, kteří mají opakované infekční komplikace, včetně vleklých lokálních defektů (typu dekubitů, gangrény periferních částí končetin, s pozitivními kultivačními nálezy virulentních mikrobů, rezistentních na antibiotickou terapii) a opakovaných septických stavů, mají závažnou anemii, opakované trombotické komplikace aj., nelze očekávat přínos z léčby ICD a dosavadní klinické zkušenosti hovoří jasně proti uvedené indikaci. ${ }^{192}$

\subsubsection{Zvýšené riziko lékové proarytmie}

U pacientů, kteří užívají více léčiv, které mohou ovlivňovat komorovou repolarizaci, je zvýšené riziko vzniku lékové proarytmie. Ta se může manifestovat též jako s-KA, často typu torsade de pointes při léky navozeném prodlouženém intervalu QTc. Mưže to být u pacienta s kongenitálním syndromem dlouhého intervalu QT, ale i u pacienta s normálním QTc, ale s tzv. sníženou repolarizační rezervou, tedy s latentním syndromem dlouhého intervalu QT. Ten se tedy klinicky manifestuje až při určité zátěži, kterou může být např́iklad iontová dysbalance (hypokalemie, hypomagnesemie) či podání léčiv, které prodlužují repolarizační fázi komorového akčního potenciálu. ${ }^{3}$ Mezi faktory, které zvyšují riziko lékové proarytmie, patří: starší věk (> 65 roků), ženské pohlaví, strukturální srdeční onemocnění, kongenitální syndrom dlouhého intervalu QT, snížená funkce ledvin, jater, opakované významnější iontové dysbalance, výraznější hyponutrice s iontovou dysbalancí a hypoalbuminemií (např. u těžších forem anorexia nervosa). ${ }^{3,193,94}$ Patří sem i anamnéza předchozí lékové proarytmie. Je celá řada „rizikových“léčiv, které mohou prodlužovat interval QTc na EKG a vyvolávat proarytmii v podobě komorové tachykardie typu torsade de pointes. ${ }^{195}$ Sem patři naprríklad tricyklická antidepresiva i další psychofarmaka, antimykotika, některá prokinetika, většina antiarytmik, některá antibiotika a celá řada dalších léčiv. Jejich seznam i upozornění na rizikové lékové interakce jsou uvedeny na internetu na př́slušných webových stránkách (www.qtdrugs.org, www.torsades.org). ${ }^{3}$ Je třeba mít na paměti, že většina lékových interakcí a nežádoucích účinků léků včetně lékové proarytmie je podmíněna genetickým polymorfismem biotransformačních enzymů (cytochromu P 450 - zejména CYP 3A4 a CYP 2D6), který způsobuje velké rozdíly v metabolizaci určitého léčiva mezi 
jednotlivými pacienty (rychlí a pomalí metabolizátoři) a je přičinou případného snadného předávkování určitého léku u konkrétního pacienta či vzniku nežádoucí lékové interakce, jejímž projevem může být i komorová arytmie. Při medikamentózní léčbě s použitím léčiv s vyšším potenciálem lékové proarytmie je třeba věnovat zvýšenou pozornost výskytu nežádoucích účinků dané medikace. ${ }^{3}$

\section{Závěr}

Současná verze Doporučených postupů pro diagnostiku a léčbu komorových arytmií se snaží reflektovat nová data $\mathrm{v}$ rámci zásad medicíny založené na důkazech. Pozornost je soustředěna především na léčbu hemodynamicky a prognosticky závažných forem komorových arytmií, které jsou hlavním podkladem náhlé srdeční smrti. Zde má v dnešní době dominantní postavení nefarmakologická léčba.

$\mathrm{U}$ pacientů s výrazně zvýšeným rizikem náhlé srdeční smrti je jednoznačně preferována implantace kardioverteru-defibrilátoru. Riziková stratifikace a obecně akceptované indikace této léčby jsou uvedeny u jednotlivých diagnostických jednotek.

$\mathrm{V}$ řadě případo̊ $\mathrm{s}$ manifestací chronického srdečního selhání je léčba ICD kombinována s optimalizovanou farmakoterapií a s možností stimulační srdeční resynchronizační terapie.

K docílení většího efektu léčby a jejího komfortu pro pacienta a s cílem prodloužit životnost funkce ICD je $\mathrm{u}$ řady pacientů s recidivujícími komorovými arytmiemi možno doplnit léčbu ICD katetrizační ablací - respektive ovlivněním arytmogenního substrátu.

U idiopatických komorových tachykardií a některých frekventních symptomatických komorových extrasystol, bez strukturálního srdečního postižení, představuje katetrizační ablace kurativní výkon.

Léčba pacientů s maligními komorovými arytmiemi má být provádèna $v$ centrech, která jsou schopna poskytnout u této diagnózy komplexní léčebnou péči a nepřetržitý servis při řešení akutních často dramatických medicínských stavů, např́klad při nepřetržité komorové tachykardii či při tzv. arytmické bouři u pacientů s ICD.

U pacientů s potenciálně maligními komorovými arytmiemi či se zvýšeným rizikem náhlé srdeční smrti zatím posuzování indikace $\mathrm{k}$ uvedené nefarmakologické léčbě (zejména indikace $\mathrm{k}$ ICD v rámci primární profylaxe náhlé srdeční smrti) respektuje navržená schémata opírající se o údaje z relevantních klinických studií, velkých metaanalýz či o konsensus expertů. ${ }^{3}$

$\mathrm{V}$ předloženém materiálu jsou zároveň komentovány limity současné stratifikace rizika náhlé srdeční smrti a u některých kardiálních onemocnění naznačen další směr výzkumu, který by směřoval k optimalizaci léčby, která zatím není dostatečně medicínsky a ekonomicky efektivní.

Současná verze těchto doporučení klade větší důraz na individuální posuzování, které bere na zřetel celkový stav pacienta, vývoj kardiálního onemocnění a další komorbidity, které mohou významně limitovat efekt případné antiarytmické léčby. Lze očekávat, že i nadále bude posilovat toto hledisko výběru a vedení léčby dle komplexního zvážení všech ukazatelů, které mohou hrát roli pro další životní prognózu konkrétního pacienta. Indikace jednotlivých postupů léčby budou ovlivňovány novými poznatky základního a klinického výzkumu. Léčba komorových tachykardií je dynamický dlouhodobý proces a aktualizace opodstatněných stanovisek na léčbu v určité době je mimo jiné předmětem opakovaných inovací zmíněných doporučených postupů.

\section{Literatura}

1. Epstein AE, DiMarco JP, Ellenbogen KA, et al. ACC/AHA/HRS 2008 guidelines for device-based therapy of cardiac rhythm abnormalities. Circulation 2008;117:2820-2840.

2. Táborský M, Kautzner J, Bytešník J, et al. Zásady pro implantace kardiostimulátorů, implantabilních kardioverterů-defibrilátorů a systémů pro srdeční resynchronizační léčbu 2009. Cor Vasa 2009;51:602-614.

3. Zipes DP, Camm AJ, Borggrefe M, et al. ACC/AHA/ESC 2006 guidelines for management of patients with ventricular arrhythmias and the prevention of sudden cardiac death. Europace 2006;8:746-837.

4. Aliot EM, Stevenson WG, Almendral-Garrote JM, et al. EHRA/HRS expert consensus on catheter ablation of ventricular arrhythmias. Europace 2009;11:771-817.

5. Dickstein K, Vardas PE, Auricchio A, et al. 2010 focused update of ESC guidelines on device therapy in heart failure. Eur Heart J 2010;31:2677-2687.

6. Moss AJ, Hall WJ, Cannom DS, et al., for the MADIT-CRT Trial Investigators. N Engl J Med 2009;361:1329-1338.

7. Kautzner J, Bytešník J, Vančura $V$, et al. Poruchy srdečního rytmu. In: Klinická kardiologie. Vojáček J, Kettner J (eds.). Hradec Králové: Nucleus, 2009:239-335.

8. Adamec J, Adamec R. Ekg podle Holtera. Elektrokardiografická interpretace. Praha: Galén, 2003;48-50, 105-107.

9. Josephson ME. Clinical Cardiac Electrophysiology. Techniques and interpretation. 3rd edition. Philadelphia: Lippincott Williams and Wilkins, 2002:425-610, 658-863.

10. Myerburg RJ, Kessler KM, Luceri RM, et al. Classification of ventricular arrhythmias based on parallel hierarchies of frequency and form. Am J Cardiol 1984;54:1355-1359.

11. Zheng ZJ, Croft JB, Giles WH, Mensah GA. Sudden cardiac death in the United States, 1989 to 1998. Circulation 2001;104:2158-2163.

12. Kong MH, Fonarow GC, Peterson ED, et al. Systematic review of the incidence of sudden cardiac death in the United States. J Am Coll Cardiol 2011;57:794-801.

13. Moss AJ. MADIT-II and its implications. Eur Heart J 2003;24:16-18.

14. Nichol G, Thomas E, Callaway CW, et al. Regional variation in out-of-hospital cardiac arrest incidence and outcome. JAMA 2008;300:1423-1431.

15. Kong MH, Fonarow GC, Peterson ED, et al. Systematic review of the incidence of sudden cardiac death in the United States. J Am Coll Cardiol 2011;57:794-801.

16. Anderson MH. Risk assessment of ventricular tachyarrhythmias. Clinical approaches to tachyarrhythmias. Camm AJ. Armonk (eds.). NY: Futura Publishing Co., Inc., 1995:1-39.

17. Horowitz LN. Ventricular arrhythmias: recognition and treatment. In: Nacarelli GV (ed.): Cardiac arrhythmias: a practical approach. Mount Kisco, NY: Futura Publishing Co., Inc., 1991:93-115.

18. Bigger JT, Jr. Definition of benign versus malignant ventricular arrhythmias: targets for treatment: Am J Cardiol 1983;52:47C-54C.

19. Morganroth J. Indications for antiarrhythmic suppression of ventricular arrhythmias: a definition of life-threatening ventricular arrhythmias. Am J Cardiol 1993;72:3A-7A.

20. Mehta D, Curwin J, Gomes JA, Fuster V. Sudden death in coronary artery disease. Acute ischemia versus myocardial substrate. Circulation 1997;96:3215-3223.

21. Crawford T, Cowger J, Desjardins B, et al. Determinants of postinfarction ventricular tachycardia. Circ Arrhythm Electrophysiol 2010;3:624-631.

22. Lerman BB. Mechanism of outflow tract tachycardia. Heart Rhythm 2007;4:973-976. 
23. Firouzi M, Groenewegen WA. Gene polymorphisms and cardiac arrhythmias. Europace 2003;5:235-242.

24. Larsen L, Markham J, Haffajee Cl. Sudden death in idiopathic dilated cardiomyopathy: role of ventricular arrhythmia. Pacing Clin Electrophysiol 1993;16:1051-1059.

25. Rubin AM, Morganroth J, Kowey PR. Ventricular premature depolarizations. In: Cardiac Arrhythmia. Mechanisms, Diagnosis and Management. Ed. Podrid PJ, Kowey PR. Baltimore: Williams and Wilkins 1995:891-906.

26. Michelson EL, Morganroth J. Spontaneous variability of complex ventricular arrhythmia detected by long-term electrocardiopgaphic recording. Circulation 1980;61:690-695.

27. Pratt CM, Slymen DJ, Wierman AM, et al. Analysis of the spontaneous variability of ventricular arrhythmias: consecutive ambulatory electrocardiographic recordings of ventricular tachycardia. Am J Cardiol 1985;56:67-72.

28. Monserrat L, Elliot PM, Gimeno JR, et al. Non-sustained ventricular tachycardia in hypertrophic cardiomyopathy: an independent marker of sudden death risk in young patients. J Am Coll Cardiol 2003;42:873-9.

29. Al-Khatib S, Stebbins AL, Califf RM, et al. Sustained ventricular arrhythmias and mortality among patients with acute myocardial infarction: results from the GUSTO-III trial. Am Heart J 2003;145:515-521.

30. Becker LB, Smith DW, Rhodes KV. Incidence of cardiac arrest: a neglected factor in evaluating survival rates. Ann Emerg Med 1993;22:86-91.

31. Vreede-Swagemakers JJ, Gorgels AP, Dubois-Arbouw WI, et al. Out-of-hospital cardiac arrest in the 1990's: a population-based study in the Maastricht area on incidence, characteristics and survival. J Am Coll Cardiol 1997;30:1500-1505.

32. Myerburg RJ, Castellanos A. Cardiac arrest and sudden cardiac death. In: Braunwald $E$, ed. Heart disease: a textbook of cardiovascular medicine. New York: WB Saunders Publishing Co., 1997:742-779.

33. Sans $S$, Kesteloot $H$, Kromhout D. The burden of cardiovascular diseases mortality in Europe. Task Force of the European Society of Cardiology on Cardiovascular Mortality and Morbidity Statistics in Europe. Eur Heart J 1997; 18:1231-1248.

34. Bayes de Luna A, Coumel P, Leclercq JF. Ambulatory sudden cardiac death: mechanisms of production of fatal arrhythmia on the basis of data from 157 cases. Am Heart J 1989;117:151-159.

35. Volpi A, Cavalli A, Turato R, et al. Incidence and short-term prognosis of late sustained ventricular tachycardia after myocardial infarction: results of the Gruppo Italiano per lo Studio della Sopravvivenza nell'Infarto Miocardico (GISSI-3) data base. Am Heart J 2001;142:87-92.

36. Kautzner J, Bytešník J. Tachykardie se širokým QRS komplexem: Přehled diferenciální diagnostiky. Prakt Lékař 1997;77:381-386.

37. Brugada $P$, Brugada J, Mont $L$, et al. A new approach to the differential diagnosis of a regular tachycardia with a wide QRS complex. Circulation 1991;83:1649-1659.

38. Myerburg RJ, Kessler KM, Castellanos A. Sudden cardiac death. Structure, function, and time-dependence of risk. Circulation 1992;81(Suppl): 12-10.

39. Chen $X$, Shenasa M, Borggreffe $M$, et al. Role of programmed ventricular stimulation in patients with idiopathic dilated cardiomyopathy and documented sustained ventricular tachyarrhythmias: inducibility and prognostic value in 102 patients. Eur Heart J 1994;15:76-82.

40. Goldberger JJ, Cain ME, Hohnloser SH, et al. AHA/ACC/HRS scientific statement of noninvasive risk stratification techniques for identifying patients at risk for sudden cardiac death. J Am Coll Cardiol 2008:52:1179-1199.

41. Huikuri HV, Raatikainen MJP, Moerch-Joergensen RM, et al., for the CARISMA study group. Prediction of fatal or near-fatal cardiac arrhythmia events in patients with depressed left ventricular function after an acute myocardial infarction. Eur Heart J 2009;30:689-698.

42. Huikuri HV, Tapanainen JM, Lindgren $\mathrm{K}$, et al. Prediction of sudden cardiac death after myocardial infarction in the beta-blocking era. J Am Coll Cardiol 2003;42:652-658.

43. Moss AJ, Hall WJ, Cannom DS, et al. Improved survival with an implanted defibrillator in patients with coronary disease at high risk for ventricular arrhythmia. N Engl J Med 1996;335:1933-1940.

44. Komajda M, Jais JP, Reeves F, et al. Factors predicting mortality in idiopathic dilated cardiomyopathy. Eur Heart J 1990;11:824-831.

45. Kelly $P$, Coats A. Variation in mode of sudden cardiac death in patients with idiopathic dilated cyrdiomyopathy. Eur Heart J 1997;18:879-880.

46. Grimm W, Christ M, Bach J, et al. Noninvasive arrhythmia risk stratification in idiopathic dilated cardiomyopathy study. Circulation 2003;108:2883-2891.
47. Grimm W, Christ M, Maisch B. Long runs of non-sustained ventricular tachycardia on 24-hour ambulatory electrogram predict major arrhythmic events in patients with idiopathic dilated cardiomyopathy. Pacing Clin Electrophysiol 2005;28:S207-S210.

48. Fananapazir L, Chang AC, Epstein SE, et al. Prognostic determinants in hypertrophic cardiomyopathy. Prospective evaluation of a therapeutic strategy based on clinical, Holter, haemodynamic, and electrophysiological findings. Circulation 1992;86:730-740.

49. Maron BJ, McKenna WJ, Danielson GK, et al. ACC/ESC Clinical Expert Consensus Document on Hypertrophic Cardiomyopathy. Eur Heart J 2003;24:1965-1991.

50. Kofflard MJM, Ten Cate FJ, van der Lee C, van Domburg RT. Hypertrophic cardiomyopathy in a large community-based population: clinical outcome and identification of risk factors for sudden cardiac death and clinical deterioration. J Am Coll Cardiol 2003;41:987-993.

51. McKenna WJ, Sadoul N, Slade AK, Saumarez RC. The prognostic significance of nonsustained ventricular tachycardia in hypertrophic cardiomyopathy. Circulation 1994;90:3115-3117.

52. Gimeno JR, Tomé-Esteban M, Lofiego C, et al. Exercise-induced ventricular arrhythmias and risk of sudden cardiac death in patients with hypertrophic cardiomyopathy. Eur Heart J 2009;30:2599-2605.

53. Marcus FI, McKenna WJ, Sherrill D, et al. Diagnosis of arrhythmogenic right ventricular cardiomyopathy/dysplasia. Proposed modification of the Task Force criteria. Circulation 2010;121:1533-1541.

54. Berder V, Vauthier $M$, Mabo $P$, et al. Characteristics and outcome in arrhythmogenic right ventricular dysplasia. Am J Cardiol 1995;75:411-414.

55. Corrado D, Leoni L, Link MS, et al. Implantable cardioverter-defibrillator therapy for prevention of sudden death in patients with arrhythmogenic right ventricular cardiomyopathy/dysplasia. Circulation 2003;108:3084-3091.

56. Wichter T, Paul M, Wollmann C, et al. Implantable cardioverter-defibrillator therapy in arrhythmogenic right ventricular cardiomyopathy: Single-center experience of long-term follow-up and complications in 60 patients. Circulation 2004;109:1503-1508.

57. Santangeli P, Pieroni M, Dello Russo A, et al. Noninvasive diagnosis of electroanatomic abnormalities in arrhythmogenic right ventricular cardiomyopathy. Circ Arrhyth Electrophysiol 2010;3: 632-638.

58. McKoy G, Protonotarios N, Crosby A, et al. Identification of a deletion in plakoglobin in arrhythmogenic right ventricular cardiomyopathy with palmoplantar keratoderma and wolly hair (Naxos disease). Lancet 2000;355:2119-2124.

59. Dalal D, Nassir K, Bomma C, et al. Arrhythmogenic right ventricular dysplasia. A United States experience. Circulation 2005;112:3823-3832.

60. Nugent AW, Daubeney PEF, Chondros P, et al. Tle epidemiology of childhood cardiomyopathy in Australia. N Engl J Med 2003;348: 1639-1646.

61. Murphy RT, Thaman R, Blanes JG, et al. Natural history and familial characteristics of isolated left ventricular noncompaction. Eur Heart J 2005;26:187-192.

62. Kobza R, Jenni R, Erne $P$, et al. Implantable cardioverter-defibrillators in patients with left ventricular noncompaction. PACE 2008;31:461-467.

63. Oechslin E, Attenhofer JCH, Rojas JR, et al. Long-term follow-up of 34 adults with isolated left ventricular noncompaction: a distinct cardiomyopathy with poor prognosis. J Am Coll Cardiol 2000;36:493-500.

64. Linhartová K. Restriktivní kardiomyopatie. In: Kardiomyopatie. Ed. Veselka J, Linhartová K, Zemánek D, et al. Praha: Galén, 2009:57-87.

65. McCarthy RE, Kasper EK. A review of the amyloidoses that infiltrate the heart. Clin Cardiol 1998;21:547-552.

66. Dispenzieri A, Kyle RA, Gertz MA, et al. Survival in patients with primary systemic amyloidosis and raised serum cardiac troponin. Lancet 2003;361:1787-1789.

67. Winters SL, Cohen M, Greenberg S, et al. Sustained ventricular tachycardia associated with sarcoidosis: Assessment of the underlying cardiac anatomy and the prospective utility of programmed ventricular stimulation, drug therapy and implantable antitachycardia device. J Am Coll Cardiol 1991;18: 937-943.

68. Paz HL, McCormick DJ, Kutalek S, Patchevsky A. The automated implantable cardiac defibrillator. Prophylaxis in cardiac sarcoidosis. Chest 1994;106:1603-1607.

69. Lubitz SA, Goldberg SH, Mehta D. Sudden cardiac death in infiltrative cardiomyopathies: Sarcoidosis, scleroderma, amyloidosis, hemochromatosis. Progress Cardiovasc Dis 2008;51:58-73. 
70. Sachdev B, Takenaka T, Teraguchi H, et al. Prevalence of Anderson-Fabry disease in male patients with late onset hypertrophic cardiomyopathy. Circulation 2002;105:1407-1411.

71. Whybra C, Kampmann C, Willers I, et al. Anderson-Fabry disease: clinical manifestations of disease in female heterozygotes. J Inherit Metab Dis 2001;24:715-24.

72. Patel MR, Cecchi F, Cizmarik M, et al. Cardiovascular events in patients with Fabry disease. J Am Coll Cardiol 2011;57:1093-1099.

73. Elliott $P$, Andersson $B$, Arbustini $F$, et al. Classification of the cardiomyopathies: a position of statement from the European Society of Cardiology Working Group on myocardial and pericardial diseases. Eur Heart J 2008;29:270-276.

74. Di Castelnuovo A, Costanzo S, Bagnardi V, et al. Alcohol dosing and total mortality in men and women an updated meta-analysis of 34 prospective studies. Arch Intern Med 2006;166:2437-2445.

75. Meune C, Van Berlo JH, Anselme F, et al. Primary prevention of sudden death in patients with lamin $A / C$ gene mutations. $N$ Engl J Med 2006;354:209-210.

76. Priori SG, Barhanin J, Hauer RNW, et al. Genetic and molecular basis of cardiac arrhythmias. Impact on clinical management. Eur Heart J 1999;20:174-195.

77. Zareba W, Moss A, Schwartz P, et al. International Long QT Syndrome Registry Research Group: influence of the genotype on the clinical course of the long QT syndrome. N Engl J Med 1998;339:960-965.

78. Fowler SJ, Napolitano C, Priori SG. When is genetic testing useful in patients suspected to have inherited cardiac arrhythmias? Curr Opin Cardiol 2010;25:37-45.

79. Schwartz P, Priori S, Spazzolini C, et al. Genotype-phenotype correlation in the long-QT syndrome. Gene-specific triggers for life-threatening arrhythmias. Circulation 2001;103:89-95.

80. Priori SG, Schwartz PJ, Napolitano C, et al. Risk stratification in the long-QT syndrome. N Engl J Med 2003;348:1866-1874.

81. Garrat CJ, Elliot P, Behr E, et al. Heart Rhythm UK position statement on clinical indications for implantable cardioverter defibrillators in adult patients with familial sudden cardiac death syndromes. Europace 2010;12:1156-1175.

82. Zareba W, Moss AJ, Daubert JP, et al. Implantable cardioverter defibrillator in high-risk long QT syndrome patients. J Cardiovasc Electrophysiol 2003;14:337-341.

83. Gussak I, Brugada P, Brugada J, et al. Idiopathic short QT interval: A new clinical syndrome? Cardiology 2000;94:99-102.

84. Brugada R, Hong K, Dumaine R, et al. Sudden death associated with short-QT syndrome linked to mutations in HERG. Circulation 2003;108:3092-3096.

85. Gollob MH, Redpath CJ, Roberts JD. Tle short QT syndrome. Proposed diagnostic criteria. J Am Coll Cardiol 2011;57:802-812.

86. Brugada P, Brugada J. Right bundle branch block, persistent ST-segment elevation and sudden cardiac death: a distinct clinical and electrocardiographic syndrome. A multicenter report. J Am Coll Cardiol 1992;20:1391-1396.

87. Brugada R, Brugada J, Antzelevitch C, et al. Sodium channel blockers identify risk for sudden death in patients with ST-segment elevation and right bundle branch block but structurally normal hearts. Circulation 2000;101:510-515.

88. Brugada J, Brugada R, Brugada P. Determinants of sudden cardiac death in individuals with the electrocardiographic pattern of Brugada syndrome and no previous cardiac arrest. Circulation 2003;108:3092-3096.

89. Probst V, Veltmann C, Eckardt $L$, et al. Long-term prognosis of patients diagnosed with Brugada syndrome. Results from the FINGER Brugada syndrome registry. Circulation 2010;121:635-643.

90. Klatsky AL, Oehm R, Cooper RA, et al. The early repolarization normal variant electrocardiogram: correlates and consequences. Am J Med 2003;115:171-177.

91. Tikkanen JT, Anttonen O, Juhani Junttila M, et al. Long-term outcome associated with early repolarization on electrocardiography. N Engl J Med 2009;361:2529-2537.

92. Haissaguerre M, Derval N, Sacher F, et al. Sudden cardiac arrest associated with early repolarization. N Engl J Med 2008;358:2016-2023.

93. Cappato R, Furlanelo F, Giovinazzo V, et al. J wave, QRS slurring, and ST elevation in athletes with cardiac arrest in the absence of heart disease. Marker of risk or innocent bystander? Circ Arrhythm Electrophysiol 2010;3: 305-411.
94. Gussak I, Antzelevitch C. Early repolarization syndrome: clinical characteristics and possible cellular and ionic mechanisms. J Electrocardiol 2000;33:299-309.

95. Zicha S, Xiao I, Stafford S, et al. Transmural expession of transient outward potassium current subunits in normal and failing canine and human hearts. J Physiol 2004;561:735-748.

96. Patel RB, Ng J, Reddy V, et al. Early repolarization associated with ventricular arrhythmias in patients with chronic coronary artery disease. Circ Arrhythm Electrophysiol 2010;3:489-495.

97. Lahat H, Eldar M, Levy-Nissenbaum E, et al. Autosomal recessive catecholamine- or exercise-induced polymorphic ventricular tachycardia: Clinical features and assignment of the disease gene to chromosome 1p13-21. Circulation 2001;103:2822-2827.

98. Priori SG, Napolitano C, Memmi M, et al. Clinical and molecular characterization of patients with catecholaminergic polymorphic ventricular tachycardia. Circulation 2002;106:69-74.

99. Napolitano C, Priori SG. Diagnosis and treatment of catecholaminergic polymorphic ventricular tachycardia. Heart Rhythm 2007;4:675-678.

100. Novotný $T$, Kubuš $P$, Vít $P$, et al. Klinická charakteristika tř́ českých rodin s katecholaminergní polymorfní komorovou tachykardií a pilotní výsledky mutační analýzy genu RyR2. Cor Vasa 2010;52:39-42.

101. Leenhardt A, Glaser E, Burguera M, et al. Short-coupled variant of torsade de pointes: a new electrocardiographic entity in the spectrum of idiopathic ventricular tachyarrhythmias. Circulation 1994;89:206-215.

102. Janousek J, Paul T, Bartakova $\mathrm{H}$. Role of late potentials in identifying patients at risk for ventricular tachycardia after surgical correction of congenital heart disease. Am J Cardiol 1995;75:146-150.

103. Natale A, Raviele A, Al-Ahmad A, et al. Venice Chart International Consensus Document on Ventricular Tachycardia/Ventricular Fibrillation Ablation. J Cardiovasc Electrophysiol 2010;21:339-379.

104. Chinushi M, Aizawa $Y$, Kitazawa $H$, et al. Successful radiofrequency catheter ablation for macroreentrant ventricular tachycardia in a patient with tetralogy of Fallot after corrective surgery. PACE 1995;18: 1713-1716.

105. Liberthson RR. Sudden death from cardiac causes in children and young adults. N Engl J Med 1996;334:1039-1044.

106. Fontaine $G$, Fornes $P$, Fontaliran $F$, et al. Myocarditis as a cause of sudden death response. Circulation 2001;103:12.

107. Chiale PA, Halperin MS, Nau GJ, et al. Malignant ventricular arrhythmias in chronic chagasic myocarditis. PACE 1995;18:162-172.

108. Tai YT, Lau CP, Fong PC, et al. Incessant automatic ventricular tachycardia complicating acute coxsackie B myocarditis. Cardiology 1992;80:339-344.

109. Cooper LT, Jr. Giant cell myocarditis: diagnosis and treatment. Herz 2000;25:291-298.

110. Bartůněk $P$. Lymeská karditida. In: Kardiologie. Ed. Aschermann $M$, et al. Praha: Galén, 2004:847-851.

111. Rassi A, Jr., Rassi A, Little WC. Chagas' heart disease. Clin Cardiol 2000;23:883-889.

112. Muratore $C$, Rabinovich $R$, Iglesias $R$, et al. Implantable cardioverter-defibrillators in patients with Chagas' disease: are they different from patients with coronary disease? Pacing Clin Electrophysiol 1997;20: 194-197.

113. Maione $S$, Valentin G, Giunta A, et al. Cardiac involvment in rheumatoid arthritis. Cardiology 1993;83:234.

114. MERIT-HF study group. Effect of metoprolol CR/XL in chronic heart failure: Metoprolol CR/XL Randomised Intervention Trial in Congestive Heart Failure (MERIT-HF). Lancet 1999;353:2001-2007.

115. Bardy GH, Lee KL, Mark DB, et al., for the Sudden Cardiac Death in Heart Failure Trial (SCD-HeFT) Investigators. Amiodarone or an implantable cardioverter-defibrillator for congestive heart failure. $\mathrm{N}$ Engl J Med 2005:352:225-237.

116. Bristow MR, Saxon LA, Boehmer J, et al., for COMPANION Investigators. Cardiac-resynchronization therapy with or without an implantable defibrillator in advanced chronic heart failure. N Engl J Med 2004;350: 2140-2150.

117. Cleland JGF, Daubert JC, Erdmann E, et al., for CARE-HF Study Investigators. The effect of cardiac resynchronization on morbidity and mortality in heart failure. N Engl J Med 2005;352:1539-1549.

118. Moss AJ, Hall WJ, Cannom DS, et al., for the MADIT-CRT Investigators. Cardiac-resynchronization therapy for the prevention of heart-failure events. N Engl J Med 2009;361:1329-1338. 
119. Zareba W, Klein H, Cygankiewicz l, et al. Effectiveness of cardiac resynchronization therapy by QRS morphology in the Multicenter Automatic Defibrillator Implantation Trial - Cardiac Resynchronization Therapy (MADIT-CRT). Circulation 2011;123:1061-1072.

120. Málek I, Marek T. Dlouhodobá péče o nemocné po ortotopické transplantaci srdce. In: Transplantace srdce. Ed. Pirk J, Málek I, et al. Praha: Karolinum, 2008:115-161.

121. Mills RM, Jr., Naftel DC, Kirklin JK, et al., and the transplant research database. Heart transplant rejection with hemodynamic compromise: a multi-institutional study of the role of endomyocardial cellular infiltrate. J Heart Lung Transplant 1997;16:813-821.

122. Grimm M, Rinaldi M, Zonan NA, et al. Superior prevention of acute rejection by tacrolimus vs. cyclosporine in heart transplant recipients. A large European trial. Am J Transplant 2006;6:1387-1397.

123. Viskin S, Belhassen B. Idiopathic ventricular fibrillation. Am Heart J 1990;120:661-671.

124. Priori SG, Crotti L. Idiopathic ventricular fibrillation. Cardiac Electrophysiol Rev 1999;3:198-201.

125. Chen Q, Kirsch GE, Zhang D, et al. Genetic basis and molecular mechanism for idiopathic ventricular fibrillation. Nature 1998;392:293-294.

126. Priori SG, Borggrefe M, Camm AJ, et al. Role of the implantable defibrillator in patients with idiopathic ventricular fibrillation. Data from the UCARE International Registry. PACE 1995;18:799.

127. The beta-blocker heart attack study group. The beta-blocker heart attack trial. JAMA 1981;246:2073-2074.

128. The Norwegian Multicenter Study Group: Timolol-induced reduction in mortality and reinfarction in patients surviving acute myocardial infarction. N Engl J Med 1981;304:801-807.

129. Hjalmarson L, Elmfeldt $D$, Herlitz J, et al. Effect on mortality of metoprolol in acute myocardial infarction: a double-blind randomised trial. Lancet 1981;2:823-827.

130. Singh BN, Jewitt DE. Beta-adrenoreceptor blocking drugs in cardiac arrhythmias. Cardiovasc Drugs 1997;2:119-159.

131. Packer $M$, Coats AJS, Fowler MB, et al.; for the carvedilol prospective randomized cumulative survival study group. Effect of carvedilol on survival in severe chronic heart failure. N Engl J Med 2001;344:1651-1658.

132. Poole-Wilson PA, Swednerg K, Cleland JCF, et al., for the COMET investigators Comparison of carvedilol and metoprolol on clinical outcomes in patients with chronic heart failure in the carvedilol or metoprolol european trial (COMET): randomised controlled trial. Lancet 2003;362:7-13.

133. Echt DS, Leibson PR, Mitchell LB, et al. Mortality and morbidity in patients receiving encainide, flecainide, or placebo. The Cardiac Arrhythmia Suppression Trial. N Engl J Med 1991;324:781-788.

134. Amiodarone Trials Meta-Analysis Investigators: Effect of prophylactic amiodarone on mortality after acute myocardial infarction and in congestive heart failure: meta-analysis of individual data from 6500 patients in randomised trials. Lancet 1997;350:1417-1424.

135. International Liaison Committee on Resuscitation. 2005 International consensus on cardiopulmonary resuscitation and emergency cardiovascular care science with treatment recommendastion. Resuscitation 2005;67:181-341.

136. Garza AG, Gratton MC, Salomone JA, et al. Improved patient survival using a modified resuscitation protocol for out-of-hospital cardiac arrest. Circulation 2009;119:2597-2605.

137. Priori SG, Bossaert LL, Chamberlain DA, et al. ESC-ERC recommendations of the use of automated external defibrillators (AEDs) in Europe. Eur Heart J 2004;25:437-445.

138. Jost $D$, Degrange $H$, Verret $C$, et al.; DEFI 2005. A randomized controlled trial of the effect of automated external defibrillator cardiopulmonary resuscitation protocol on outcome from out-of-hospital cardiac arrest. Circulation 2010;121:1614-1622.

139. Alexander JH, Granger CB, Sadowski Z, et al.; for the GUSTO-I and GUSTO-IIb Investigators. Proplylactic lidocaine use in acute myocardial infarction: incidence and outcomes from from two international trials. Am Heart J 1999;137:799-805

140. Wyman MG, Wyman M, Cannom DS, Criley JM. Prevention of primary ventricular fibrillation in acute myocardial infarction with prophylactic Lidocaine. Am J Cardiol 2004:94:541-551.

141. The Antiarrhythmics Versus Implantable Defibrillators (AVID) Investigators. A comparison of antiarrhythmic-drug therapy with implantable defibrillators in patients resuscitated from near-fatal ventricular arrhythmias. N Engl J Med 1997;337:1576-1583.
142. Connolly SJ, Gent M, Roberts RS, et al. Canadian Implantable Defibrillator Study (CIDS): a randomized trial of the implantable cardioverter defibrillator against amiodarone. Circulation 2000;101:1297-1302.

143. Kuck KH, Cappato R, Siebels J, et al. Randomized comparison of antiarrhythmic drug therapy with implantable defibrillators in patients resuscitated from cardiac arrest. The Cardiac Arrest Hamburg (CASH) Study. Circulation 2000;102:748-754.

144. Connolly SJ, Hallstrom AP, Cappato R, et al. Meta-analysis of the implantable cardioverter defibrillator secondary prevention trials. Eur Heart J 200021:2071-2078.

145. Stevenson WG, Khan $H$, Sager $P$, et al. Identification of reentry circuit sites during catheter mapping and radiofrequency ablation of ventricular tachycardia late after myocardial infarction. Circulation 1993;88:1647-1670.

146. Marchlinski FE, Callans DJ, Gottlieb CD, Zado E. Linear ablation lesions for control of unmappable ventricular tachycardia in patients with ischemic and nonischemic cardiomyopathy. Circulation 2000;101:1288-1296.

147. Kautzner J, Čihák R, Peichl $P$, et al. Catheter ablation of ventricular tachycardia following myocardial infarction using three-dimensional electroanatomical mapping. PACE 2003;26:342-347.

148. Reddy VY, Neuzil P, Taborsky M, Ruskin JN. Short-term results of substrate mapping and radiofrequency ablation of ischemic ventricular tachycardia using a saline-irrigated catheter. J Am Coll Cardiol 2003;41:2228-2236.

149. Sosa E, Scanavacca M, d'Avila A, Pillegi F. A new technique to perform epicardial mapping in the electrophysiology laboratory. J Cardiovasc Electrophysiol 1996;7:531-536.

150. Sosa E, Scanavacca M, d'Avila A, et al. Nonsurgical transthoracic epicardial catheter ablation to treat recurrent ventricular tachycardia occuring late after myocardial infarction. J Am CollCardiol 2000;35:1442-1449.

151. Shumway SJ, Johnson EM, Svendsen CA, et al. Surgical management of ventricular tachycardia. Ann Thorac Surg 1997;63:1589-1591.

152. Wellens F, Geelen P, Demirsay E, et al. Surgical treatment of tachyarrhythmias due to postinfarction left ventricular aneurysm with endoaneurysmorrhaphy and cryoablation. Eur J Cardiothorac Surg 2002;22:771-776.

153. Pirk J, Bytesnik J, Kautzner J, et al. Surgical ablation of post-infarction ventricular tachycardia guided by mapping in sinus rhythm: long term results. Eur J Cardiothorac Surg 2004;26:323-329.

154. Braunschweig F, Boriani $G$, Bauer $A$, et al. Management of patients receiving implantable cardiac defibrillator shocks. Europace 2010;12:1673-1690.

155. Carbucchio C, Santamaria M, Trevisi N, et al. Catheter ablation for the treatment of electrical storm in patients with implantable cardioverter-defibrillators: short- and long-term outcomes in a prospective single-center study. Circulation 2008;117:462-469.

156. Katritsis DG, Camm AJ. Nonsustained ventricular tachycardia: where do we stand? Eur Heart J 2004:25:1093-1099.

157. Buxton $A E$, Lee $K L$, Fischer JD, et al. A randomized study of the prevention of suddden death in patients with coronary artery disease (MUSTT). N Engl J Med 1999;341:1882-1890.

158. Andresen D, Steinbeck $G$, Brüggeman T, et al. Risk stratification following myocardial infarction in the thrombolytic era. A two-step strategy using noninvasive and invasive methods. J Am Coll Cardiol 1999;33:131-138.

159. Bailey JJ, Berson A, Handelsman H, Hodges M. Utility of current risk stratification tests for predicting major arrhythmic events after myocardial infarction. J Am Coll Cardiol 2001;38:1902-1911.

160. Buxton $A E$, Lee $K L$, DiCarlo $L$, et al. Electrophysiologic testing to identify patients with coronary artery disease who are at risk for sudden death. N Engl J Med 2000;342:1937-1945.

161. Moss A. Implantable cardioverter defibrillator therapy: the sickest patients benefit the most. Circulation 2000;101:1638-1640.

162. Moss AJ, Zareba W, Hall WJ, et al. Prophylactic implantation of a defibrillator in patients with myocardial infarction and reduced ejection fraction. N Engl J Med 2002;346:877-883.

163. Wilber DJ, Zareba W, Hall WJ, et al. Time dependence of mortality risk and defibrillator benefit after myocardial infarction. Circulation 2004;109:1082-1084.

164. Hohnloser SH, Kuck KH, Dorian P, et al.; DINAMIT Investigators. Prophylactic use of an implantable cardioverter-defibrillator after acute myocardial infarction: N Engl J Med 2004;351:2481-2488.

165. Steinbeck G, Andresen D, Seidl K, et al., for the IRIS Investigators. Defibrillator implantation early after myocardial infarction. N Engl J Med 2009;361:1427-1436. 
166. Dorian $\mathrm{P}$, Hohnloser $\mathrm{SH}$, Thorpe $\mathrm{KE}$, et al. Mechanisms underlying the lack of effect of implantable cardioverter-defibrillator therapy on mortality in high-risk patients with recent myocardial infarction: insights from the Defibrillation in Acute Myocardial Infarction Trial (DINAMIT). Circulation 2010;122:2645-2652.

167. Pouleur AC, Barkoudah E, Uno $H$, et al.; for the VALIANT Investigators. Pathogenesis of sudden unexpected death in a clinical trial of patients with myocardial infarction and left ventricular dysfunction, heart failure, or both. Circulation 2010;122:597-602.

168. Goldenberg I, Gillespie J, Moss AJ, et al. Long-term benefit of primary prevention with an implantable cardioverter defibrillator. An eight year follow-up study of the Multicenter automatic defibrillator trial II. Circulation 2010;122:1265-1271.

169. Paganelli K, Barnay P, Imbert-Joscht I, et al. Influence of residual myocardial ischemia on induced ventricular arrhythmias following a first acute myocardial infarction. Eur Heart J 2001;22:1931-1937.

170. Wichterle D, Šimek J, Camm J, Malik M. Predictive characteristics of Holter-based postinfarction risk stratifiers appear superior to electrophysiological testing. PACE 2005;28(suppl 1):S182-S186.

171. Tabib A, Loire R, Chalabreysse $L$, et al. Circumstances of death and gross and microscopic observations in a series of 200 cases of sudden cardiac death associated with arrhythmogenic right ventricular cardiomyopathy and/or dysplasia. Circulation 2003;108:3000-3005.

172. Wilkoff BL, Aurricchio A, Brugada J, et al. HRS/EHRA expert consensus on the monitoring of cardiac electronic implantable devices (CIEDs): description of techniques indications, personnel, frequency, and ethical considerations. Heart Rhythm 2008;5:907-925.

173. Poole JE, Gleva MJ, Mela T, et al., for the REPLACE Registry Investigators. Complication rates associated with pacemaker or implantble cardioverter-defibrillator generator replacements and upgrade procedures. Results from the REPLACE Registry. Circulation 2010;122:1553-1561.

174. Moss AJ, Greenberg H, Case RB, et al.; for the MADIT-II Research Group Long-term clinical course of patients after termination of ventricular tachyarrhythmia by an implanted defibrillator. Circulation 2004;110:3760-3765.

175. Garcia FC, Valles E, Dhruvakumar S, Marchlinski F. Ablation of ventricular tachycardia. Herzschrittmacherther Elektrophysiol 2007;18:225-233.

176. D'Avila A. Epicardial catheter ablation of ventricular tachycardia. Heart Rhythm 2008;5(Suppl):S73-S75.

177. Oakley C, Child A, Jung B, et al. (Task Force Members). Expert consensus document on management of cardiovascular disease during pregnancy. Eur Heart J 2003;24:761-781.

178. Tau HL, Lie KI. Treatment of tachyarrhythmias during pregnancy and lactation. Eur Heart J 2001;22:458-464.

179. Král J. Kardiovaskulární onemocnění v těhotenství. In: Kardiologie. Aschermann M, et al. (eds.). Praha: Galén 2004:1357-1368.

180. Natale A, Davidson T, Geiger MJ. Implantable cardioverter defibrillators and pregnancy. A safe combination? Circulation 1997;96:2808-2812.
181. Corrado D, Basso C, Rizzoli G, et al. Does sports activity enhance the risk of sudden death in adolescents and young adults? J Am Coll Cardiol 2003;42:1959-1963.

182. Maron BJ, Doerer JJ, Haas TS, et al. Sudden deaths in young competitive athletes. Analysis of 1866 deaths in the United States, 1980-2006. Circulation 2009;119:1085-1092.

183. Heidbucherl H, Hoogsteen J, Fagard L, et al. High prevalence of right ventricular involvement in endurance athletes with ventricular arrhythmias. Eur Heart J 2003;16:1474-1480.

184. Maron BJ, Zipes DP. Introduction: eligibility recommendations for competitive athletes with cardiovascular abnormalities - general considerations. J Am Coll Cardiol 2005;45:1318-1321.

185. Pelliccia A, Maron BJ. Preparticipation cardiovascular evaluation of the competitive athlete: perspectives from the 30 -year Italian experience. Am J Cardiol 1995;75:827-829.

186. Pelliccia A, Zipes DG, Maron BJ. Bethesda Conference \# 36 and tle European Society of Cardiology consensus recommendations revisited. A comparison of U.S. and European criteria for eligibility and disqualification of competitive athletes with cardiovascular abnormalities. J Am Coll Cardiol 2008;52:1990-1996.

187. Kölbel F, Bytešník J. Kardiovaskulární systém ve stáří. In: Kardiologie. Aschermann M, et al. (eds.). Praha: Galén, 2004:1343-1355.

188. Fleg JL, Kennedy HL. Cardiac arrhythmias in a healthy elderly population: detection by 24-hour ambulatory electrocardiography. Chest 1982;81:302-307.

189. Ornato JP, Peberdy MA, Tadler SC, et al. Factors associated with the occurrence of cardiac arrest during hospitalization for acute myocardial infarction in the second national registry of myocardial infarction in the U.S. Resuscitation 2001;48:117-123.

190. Panotopoulos PT, Axtell K, Anderson AJ, et al. Efficacy of the implantable cardioverter - defibrillator in the elderly. J Am Coll Cardiol 1997;29: 556-560.

191. Geelen P, Lorga FA, Primo J, et al. Experience with implantable cardioverter - defibrillator therapy in elderly patients. Eur Heart J 1997;18: 1339-1342.

192. Eckart RE, Gula LJ, Reynolds MR, et al. Mortality following defibrillator implantation in patients with renal insufficiency. J Cardiovasc Electrophysiol 2006;17:940-943.

193. Isner JM, Roberts WC, Heymsfield SB, et al. Anorexia nervosa end sudden death. Ann Intern Med 1985;102:49-52.

194. Swenne I, Larsson PT. Heart risk associated with weight loss in anorexia nervosa and eating disorders: risk factors for QTC interval prolongation and dispersion. Acta Paediatr 1999;88:304-309.

195. Haddad PM, Anderson IM. Antipsychotic-related QTc prolongation, torsade de pointes and sudden death. Drugs 2002;62:1649-1671. 